\title{
Selected gene profiles of stressed NSC-34 cells and rat spinal cord following peripheral nerve reconstruction and minocycline treatment
}

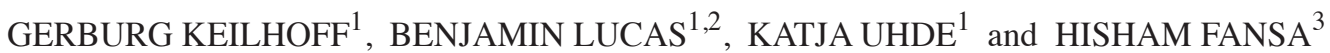 \\ ${ }^{1}$ Institute of Biochemistry and Cell Biology; ${ }^{2}$ Department of Trauma Surgery, Otto-Von-Guericke University Magdeburg, \\ Magdeburg D-39120; ${ }^{3}$ Department of Plastic, Reconstructive and Aesthetic Surgery, \\ Hand Surgery, Klinikum Bielefeld, Bielefeld D-33604, Germany
}

Received September 11, 2015; Accepted December 17, 2015

DOI: $10.3892 /$ etm.2016.3130

\begin{abstract}
The present study was conducted to investigate the effects of minocycline on the expression of selected transcriptional and translational profiles in the rat spinal cord following sciatic nerve (SNR) transection and microsurgical coaptation. The mRNA and protein expression levels of B cell lymphoma-2 (Bcl-2), Bcl-2-associated X protein (Bax), caspase-3, major histocompatibility complex I (MHC I), tumor necrosis factor- $\alpha$ (TNF- $\alpha$ ), activating transcription factor 3 (ATF3), vascular endothelial growth factor (VEGF), matrix metalloproteinase 9 (MMP9), and growth associated protein-43 (GAP-43) were monitored in the rat lumbar spinal cord following microsurgical reconstruction of the sciatic nerves and minocycline treatment. The present study used semi-quantitative reverse transcription-polymerase chain reaction (RT-PCR) and immunohistochemistry. As a PCR analysis of spinal cord tissue enabled the examination of the expression patterns of all cell types including glia, the motorneuron-like NSC-34 cell line was used to investigate expression level changes in motorneurons. As stressors, oxygen glucose deprivation (OGD) and lipopolysaccharide (LPS) treatment were performed. SNR did not induce significant degeneration of ventral horn motorneurons, whereas microglia activation and synaptic terminal retraction were detectable. All genes were constitutively expressed at the mRNA and protein levels in untreated spinal cord and control cells. SNR significantly increased the mRNA expression levels of all genes, albeit only temporarily. In all genes except MMP9 and GAP-43, the induction was seen ipsilaterally and contralaterally. The effects of minocycline
\end{abstract}

Correspondence to: Professor Gerburg Keilhoff, Institute of Biochemistry and Cell Biology, Otto-Von-Guericke University Magdeburg, 44 Leipziger Street, Magdeburg D-39120, Germany E-mail: gerburg.keilhoff@med.ovgu.de

Key words: immunohistochemistry, lipopolysaccharide, NSC-34 cell line, oxygen glucose deprivation, reverse transcription-polymerase chain reaction were moderate. The expression levels of MMP9, TNF- $\alpha$, MHC I, VEGF, and GAP-43 were reduced, whereas those of Bax and Bcl-2 were unaffected. OGD, but not LPS, was toxic for NSC-34 cells. No changes in the expression levels of Bax, caspase-3, MHC I or ATF3 were observed. These results indicated that motorneurons were not preferentially or solely responsible for SNR-mediated upregulation of these genes. MMP9, TNF- $\alpha$, VEGF and Bcl-2 were stress-activated. These results suggest that a substantial participation of motorneurons in gene expression levels in vivo. Minocycline was also shown to have inhibitory effects. The nuclear factor- $\kappa \mathrm{B}$ signalling pathway may be a possible target of minocycline.

\section{Introduction}

During embryonic and early postnatal development, the axotomy of motorneurons or removal of their target results in significant motorneuron cell loss. In adults however, axotomy can result in either complete motorneuron survival or motorneuron death. For patients this implies an incomplete or even complete loss of function of the muscular targets of the lost motorneurons (1).

It is well-established that injuries of the spinal cord $(2,3)$ as well as the peripheral nerves (4-6) lead to changes in gene and protein expression levels in motorneurons and glial cells, which may result in neuronal apoptosis. This is the basis for therapeutic strategies that aim to enhance axonal regeneration and functional recovery following peripheral nerve injury, including pharmacological treatments (7).

In this physiological context, minocycline has been widely used, but the advantages and disadvantages of this treatment appear equal in number. Minocycline is a semi-synthetic second generation tetracycline with broad spectrum anti-microbial activity (8). The primary applications of minocycline include treatment of pneumonia, rheumatoid arthritis, acne and infections of the skin, the genital, and urinary systems (9). There are also promising preclinical studies for the treatment of stroke $(10,11)$, Alzheimer's disease (12), Huntington's disease (13), Parkinson's disease (14), amyotrophic lateral sclerosis $(15)$, multiple sclerosis $(15,16)$ and traumatic brain injury (17). Clinical trials with minocycline 
for the treatment of spinal cord injury have been underway since the early 2000s (18). The predominant effect of minocycline is associated with its ability to modulate microglia and immune cell activation and to reduce apoptosis (19). There have however been reports of conflicting results, with a number of previous studies demonstrating that minocycline worsened spinal cord and brain injuries (20-23).

Our previous investigations demonstrated that minocycline impairs motorneuron survival in organotypic rat spinal cord cultures (24) and inhibited the regeneration of peripheral nerves (25). The present study was undertaken to examine the effects of minocycline on the expression of selected transcriptional and translational profiles in the rat spinal cord following sciatic nerve transection and microsurgical coaptation. In addition to the spinal cord in vivo, the present study conducted in vitro experiments using NSC-34 motorneuron-like cells. NSC-34 is a hybrid cell line produced by the fusion of neuroblastoma with mouse motorneuron-enriched primary spinal cord cells (26). These cells share numerous morphological and physiological characteristics with mature primary motorneurons, and thus are an accepted model for studying the pathophysiology of motorneurons (26). Stress was induced by oxygen glucose deprivation (OGD) or lipopolysaccharide (LPS) treatment. The mRNA and protein expression levels of the following compounds were examined: i) B cell lymphoma 2 (Bcl-2)-associated X protein (Bax), which has been demonstrated to be upregulated in the spinal motorneurons of newborn rats following sciatic nerve injury (27) and in adult cats following partial dorsal root ganglion ectomy (28); ii) caspase-3, which is activated in adult spinal motorneurons during injury-induced apoptosis (29); iii) Bcl-2, which has been reported to be activated in the adult spinal motorneurons of rats in the first three weeks following sciatic nerve injury (30); iv) major histocompatibility complex of class I (MHC I), which is upregulated in the spinal motorneurons of neonatal rats following sciatic nerve injury (31); v) tumor necrosis factor $(\mathrm{TNF}-\alpha)$, released from astrocytes and microglia around motorneurons in rat spinal cord in the first two weeks following sciatic nerve crush (32); vi) activating transcription factor (ATF3), which is a marker for regenerative response following nerve root injury (33), and its expression in neurons is closely associated with their survival and the regeneration of their axons following axotomy (34); vii) vascular endothelial growth factor (VEGF), which has been demonstrated to be upregulated in the spinal motorneurons of adult rats in response to neurotomy (35); viii) matrix metalloproteinase 9 (MMP9), immediately upregulated in adult mice spinal motorneurons following nerve injury (36); and ix) growth-associated protein 43 (GAP-43), which is expressed at high levels during development (37) and stressed by nerve injury adult motorneurons (38).

\section{Materials and methods}

Ethical approval. The present study was conducted in accordance with the European Commission regulations and those of the National Act on the Use of Experimental Animals of Germany, and adhered to the guidelines of the Committee for Research and Ethical Issues of the International Association for the Study of Pain.

\section{Animal model}

Animals. A total of 51 female Wistar rats (10 weeks old, 200-230 g, strain-matched, inbred) were obtained from Harlan-Winkelmann GmbH (Borchen, Germany). The rats were housed under controlled laboratory conditions with a 12-h light/dark cycle (lights on at $6 \mathrm{am}$ ) at $20 \pm 2^{\circ} \mathrm{C}$ with an air humidity of $55-60 \%$. The animals were provided with ad libitum access to commercial rat pellets (Altromin $1324^{\mathrm{TM}}$; Altromin Spezialfutter GmbH \& Co. KG, Lage, Germany) and tap water. Following intervention the rats were housed in pairs in Makrolon IIL cages (Bioscape GmbH, Castrop-Rauxel, Germany). Every effort was made to minimize the amount of suffering and the number of animals used in the experiments.

A total of 46 rats were injured and divided into four phosphate-buffered saline (PBS; Sigma-Aldrich Chemie GmbH, Munich, Germany) and four minocycline treatment groups with survival times of 3,5,7 and 14 days post-intervention (DPI), with five animals/group for semi-quantitative reverse transcription-polymerase chain reaction (RT-PCR). An additional three animals from the 7-day PBS-treated and from the the 7-day minocycline-treated groups were used for immunohistochemical analysis. For semi-quantitative RT-PCR the spinal cords of five untreated animals were also prepared.

Minocycline treatment. Minocycline hydrochloride (Sigma-Aldrich, St. Louis, MO, USA) was administered once daily for $\geq 7$ consecutive days by intraperitoneal injection at a dosage of $50 \mathrm{mg} / \mathrm{kg}$ body weight ( 10 times the usual human dose), starting at $30 \mathrm{~min}$ following nerve reconstruction. The drug was dissolved in saline ( $\mathrm{pH} 7.2$, freshly prepared daily) at $37^{\circ} \mathrm{C}$. A dosage of $>20 \mathrm{mg} / \mathrm{kg}$ was selected to induce the maximal anti-hyperalgesic effect, as lower doses are unable to affect gene expression in a sufficiently stable manner (39). Control rats were injected with PBS (pH 7.2) using an identical treatment regime.

Surgical protocol. The surgical procedure protocol for nerve reconstruction was the same for all groups, and consisted of exposing the right sciatic nerve through a dorsal incision under general anesthesia $(60 \mathrm{mg} / \mathrm{kg}$ pentobarbital, intraperitoneal; Sigma-Aldrich) and aseptic conditions using an SV8 operating microscope (Zeiss GmbH, Jena, Germany). The nerve was transected at the proximal origin of the gracilis muscle and immediately microsurgically coaptated with respect to intraneuronal topography using epineural sutures (Ethilon $11 \mathrm{x} 0$; Johnson \& Johnson, New Brunswick, NJ, USA) followed by closure of the dorsal incision.

Semi-quantitative RT-PCR. Following the respective survival times (3, 5, 7 and 14 days), the animals were sacrificed by an excess of anesthesia (pentobarbital) via intraperitoneal injection. L3-L6 sections of the spinal cord, divided into ipsilateral and contralateral sites were harvested and homogenized in peqGOLD TriFast total RNA isolation reagent (cat. no. 30-2030; PeqLab Biotechnologie GmbH, Erlangen, Germany) using an Ultra-Turrax Homogenizer (IKA ${ }^{\circledR}$ Werke GmbH \& Co. KG, Staufen im Breisgau, Germany). Total RNA was prepared according to the manufacturer's instructions. Potentially contaminating DNA was removed by treating $5 \mu \mathrm{g}$ total cell RNA with Turbo DNA-free (Ambion; Thermo Fisher Scientific, Inc., Waltham, MA, USA). RNA ( $4 \mu \mathrm{l} ; 2 \mu \mathrm{g}$ input RNA) was reverse transcribed using a RevertAid ${ }^{\mathrm{TM}} \mathrm{H}$ Minus First Strand cDNA Synthesis kit primed with Oligo(dT) 
primers (cat. no. K1631; Thermo Fisher Scientific, Inc.; primers listed in Table I). cDNA $(1 \mu \mathrm{l})$ was then amplified by PCR using Taq DNA polymerase (PeqLab Biotechnologie $\mathrm{GmbH}$ ), as previously described (40). One-tenth of each reaction product was electrophoresed on a $1 \%$ agarose gel (Serva Electrophoresis GmbH, Heidelberg, Germany) (excluding TNF- $\alpha$, which required a $2 \%$ agarose gel). The PCR product bands were quantified by densitometric analysis using a GeneGenius bio-imaging system (Syngene, Cambridge, UK) and the ratio of their expression levels to those of the GAPDH reference gene were calculated. Each experiment was repeated in triplicate.

Statistical analysis of all groups was conducted using a non-parametric Kruskal-Wallis test. Dunn's multiple comparison test was used as a post-hoc test. For statistical analysis of the groups within one survival time, analysis of variance with Tukey's post-hoc test was performed. Graph Pad Prism 4 software (GraphPad Software Inc., La Jolla, CA, USA) was used to conduct the statistical analyses. $\mathrm{P}<0.05$ was considered to indicate a statistically significant result.

Immunohistochemical evaluation. At 5 DPI, anesthetized rats administered an excess of intraperitoneal pentobarbital were transcardially perfused with $4 \%$ paraformaldehyde (PFA; Sigma-Aldrich). L3-L6 sections of the spinal cord were removed and postfixed for $24 \mathrm{~h}$, cryo-protected in $30 \%$ sucrose (in $0.4 \%$ buffered PFA) for $24 \mathrm{~h}$, rapidly frozen, and sectioned using a cryostat (Jung Frigocut 2800 E; Leica Microsystems GmbH, Wetzlar, Germany; $20 \mu \mathrm{m}$ ). The tissue sections were subsequently immunostained for mouse monoclonal anti-pan-neuronal neurofilament marker (neuronal marker; pan-NF SMI311; non-phosphoneurofilament specific; 1:1,000; Covance Inc., Princeton, NJ, USA) combined with the following antibodies: i) Rabbit polyclonal anti-glial fibrillary acidic protein (GFAP; astroglial marker; 1:1,000; cat. no. 10555; Progen Biotechnik GmbH, Heidelberg, Germany); ii) goat polyclonal anti-ionized calcium binding adaptor molecule 1 (IBA1; microglia marker; 1:1,000; cat. no. ab5076; Abcam, Cambridge, UK); iii) rabbit monoclonal anti-Bax (1:200; cat. no. ab32503; Abcam); iv) rabbit polyclonal anti-caspase-3 (1:100; cat. no. AB3623; EMD Millipore, Billerica, MA, USA); v) rabbit polyclonal anti-Bcl-2 (1:1,000; cat. no. AB1722; EMD Millipore); vi) rat monoclonal anti-MHC I (1:100; cat. no. ab15680; Abcam); vii) rabbit polyclonal anti-TNF- $\alpha$ (1:500; cat. no. ab9755; Abcam), and viii) rabbit polyclonal anti-MMP9 (1:100; cat. no. ab7299; Abcam) or ix) rabbit polyclonal anti-GAP-43 (1:500; cat. no. AB5220;EMD Millipore). Co-staining of mouse monoclonal anti-VEGF (1:500; cat. no. 05-1116; EMD Millipore) and mouse monoclonal anti-ATF3 (1:200; cat. no. ab191513; Abcam) was performed with rabbit polyclonal anti- $\beta$-III-tubulin $(1: 1,000$; cat. no. 802001; Biolegend, San Diego, CA, USA) as a neuronal marker. All antibodies were diluted in $1 \%$ normal goat serum and $0.3 \%$ Triton X-100 (Sigma-Aldrich) in PBS. The tissue sections were incubated overnight at $7^{\circ} \mathrm{C}$. PBS washing was conducted prior to secondary antibody incubation for $3 \mathrm{~h}$ with goat anti-mouse Alexa 488 (1:500; cat. no. A-11001; Invitrogen; Thermo Fisher Scientific, Inc.) and donkey anti-rabbit Cy3 (1:250; cat. no. 711-165-152; Dianova Vertriebs-Gesellschaft mbH, Hamburg, Germany) diluted in $1 \%$ normal goat serum and $0.3 \%$ Triton in PBS. Cryosections were mounted on slides, embedded with Immu-Mount (Thermo Fisher Scientific, Inc.) and examined under a fluorescent AxioImager M1 microscope (Zeiss GmbH, Jena, Germany) with rhodamine and fluorescein isothiocyanate filters and a Plan-Neofluar objective (20/0.5).

\section{Cell culture model}

NSC-34 cell line culture. NSC-34 cells (cat. no. CLU140; Cedarlane, Burlington, Canada) were stored at $-80^{\circ} \mathrm{C}$ in cryo tubes. In preparation for experiments, $10^{6}$ cells were pre-cultured in $15 \mathrm{ml}$ pyruvate-free Dulbecco's modified Eagle's Medium (DMEM) supplemented with $4.5 \mathrm{~g} / 1$ glucose, $10 \%$ fetal calf serum (FCS) and $0.2 \%$ Ciprobay (all Gibco ${ }^{\circledR}$; Thermo Fisher Scientific, Inc.) for 7 days in vitro (DIV) in $75-\mathrm{cm}^{2}$ flasks at $37^{\circ} \mathrm{C}$ in a humidified atmosphere containing $5 \% \mathrm{CO}_{2}$ (herein referred to as 'normal conditions'). Thereafter, the cells were harvested by scraping from the bottom, centrifuged for $10 \mathrm{~min}$ at $360 \mathrm{x} \mathrm{g}$ at room temperature, resuspended in $10 \mathrm{ml}$ DMEM (constituents as above) and seeded (0 DIV) in 96-well plates $\left(1 \times 10^{4}\right.$ cells/100 $\mu 1 \mathrm{DMEM} /$ well $)$ for assessment of cell proliferation/survival by MTT assay, and in $25-\mathrm{cm}^{2}$ flasks $\left(2 \times 10^{5}\right.$ cells $/ 5 \mathrm{ml} \mathrm{DMEM} /$ flask $)$ for semi-quantitative RT-PCR, or in $\phi 35-\mathrm{mm}$ culture dishes $\left(5 \times 10^{4}\right.$ cells $/ 2 \mathrm{ml}$ DMEM/dish) for immunohistochemistry.

Stress induction. OGD was induced following 4 DIV. Briefly, the medium was removed and replaced with normal medium under normal conditions or OGD medium (glucose-free DMEM supplemented with 10\% FCS and 0.2\% Ciprobay) under OGD conditions. OGD conditions were reached by exposing the cultures to an atmosphere composed of $5 \% \mathrm{CO}_{2}$ and $1 \% \mathrm{O}_{2}$, using nitrogen gas to displace ambient air in a C200 incubator (Labotect Technik-Göttingen GmbH, Rosdorf, Germany) at $37^{\circ} \mathrm{C}$ for $6 \mathrm{~h}$. For reoxygenation the incubator atmosphere was reestablished to $5 \% \mathrm{CO}_{2}$ and $21 \% \mathrm{O}_{2}$ and $4.5 \mathrm{mg} / \mathrm{ml}$ glucose was added.

Addition of LPS (Escherichia coli; Sigma-Aldrich) was also performed at 4 DIV. Regarding OGD, the medium was replaced with normal medium supplemented with $2 \mathrm{mg} / \mathrm{ml} \mathrm{LPS}$ for $24 \mathrm{~h}$.

Minocycline treatment. Minocycline hydrochloride (molecular weight, $493.9 \mathrm{~g} / \mathrm{mol}$; Sigma-Aldrich) was dissolved in sterile PBS to obtain a stock solution of $5 \mathrm{mg} / \mathrm{ml}$ (pH 6.5). From this stock solution, $1 \mu \mathrm{l} /$ well, $20 \mu \mathrm{l} / \mathrm{dish}$ and $50 \mu \mathrm{l} /$ flask were added to the respective groups (control, OGD, LPS) following medium replacement in order to start the stress induction (final minocycline concentration $100 \mu \mathrm{M}$, final $\mathrm{pH} 7.0$ ).

Assessment of cell proliferation/survival by MTT, bromodeoxyuridine (BrdU) and vital staining. The specific turnover of MTT (6 mg/ml; Sigma-Aldrich) to formazan by viable cells was analyzed $24 \mathrm{~h}$ following OGD induction using photometry. Briefly, $8 \mu \mathrm{l}$ MTT $(6 \mathrm{mg} / \mathrm{ml})$ was added to each well and incubated for $3 \mathrm{~h}$ prior to complete removal of the medium. A total of $100 \mu \mathrm{l}$ dimethyl sulfoxide (DMSO; Merck Millipore, Darmstadt, Germany) was then added to each well, and extinction coefficients in each well were determined using an Infinite ${ }^{\circledR}$ M200 (Tecan GmbH, Crailsheim, Germany) and calculated by subtracting the reference absorbance at $690 \mathrm{~nm}$ from the absorbance at $570 \mathrm{~nm}$. The absorbance of the empty wells filled only with DMSO was subtracted. Subsequently, the mean values of the respective treatment groups were calculated and associated with the 
芯灾

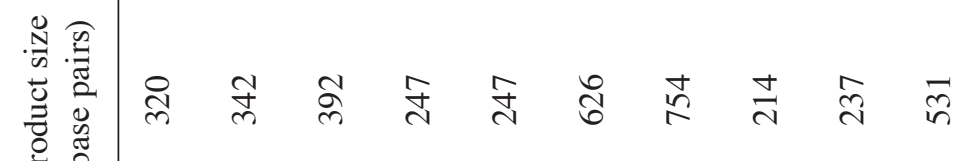

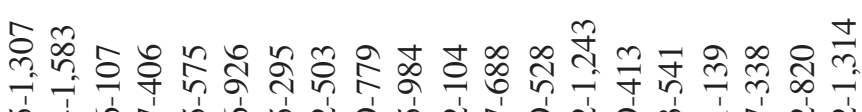

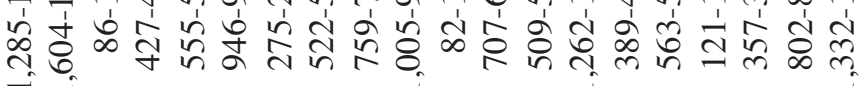

తn

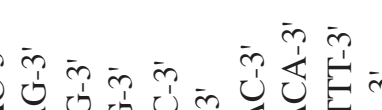

is $\overline{1}$

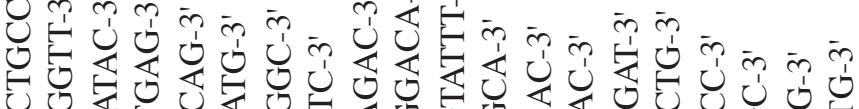

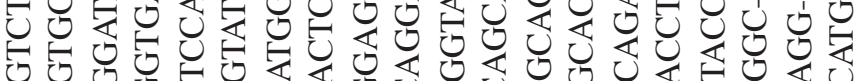

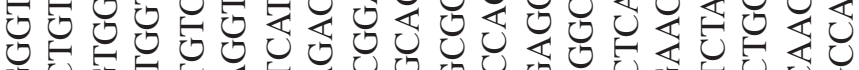

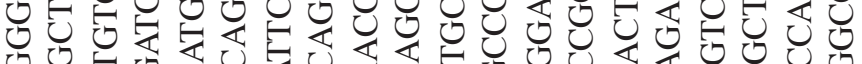

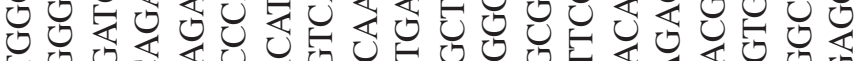

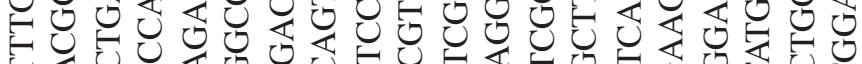

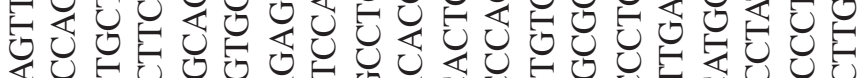

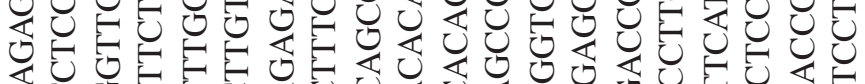

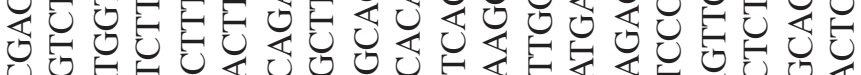

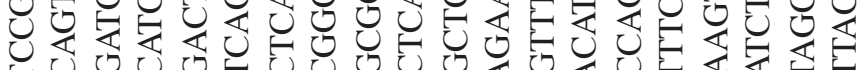

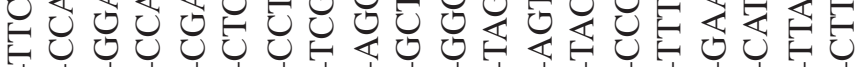

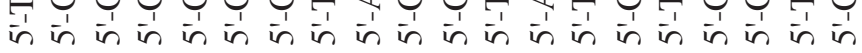


norm medium control. Each experiment was performed with 12 repeats/treatment group.

As the MTT assay is a general assay for cell viability and proliferation, the mitotic indices were additionally determined using BrdU (Roche Diagnostics GmbH, Mannheim, Germany), which was added at the same time as stress induction, and $24 \mathrm{~h}$ prior to fixation with 4\% PFA, as previously described (41). Fixed cell cultures were washed with PBS, incubated with $2 \mathrm{~N} \mathrm{HCl}$ at $37^{\circ} \mathrm{C}$ for $1 \mathrm{~h}$, washed repeatedly with borate buffer (pH 8.5) and PBS, and finally incubated at $7{ }^{\circ} \mathrm{C}$ for $24 \mathrm{~h}$ with monoclonal rat anti-BrdU antibody (1:100; cat. no. OBT0030; AbD Serotec; Bio-Rad Laboratories, Inc., Hercules, CA, USA) combined with mouse monoclonal anti-pan-NF (cat. no. 837802; Biolegend). Subsequently, the washed cultures were then incubated for $3 \mathrm{~h}$ with secondary antibodies goat anti-rat Alexa 546 (1:500; cat. no. A11081; Thermo Fisher Scientific) and anti-mouse Alexa 488 (1:500; Invitrogen; Thermo Fisher Scientific, Inc.) prior to examination using an AxioImager M1 fluorescence microscope with a 20x objective lens. Each treatment group consisted of three culture dishes in which the BrdU-positive NSC-34 cells in three different fields of view were counted. The three values/dish were combined, and the percentage of BrdU-positive cells relative to the total number of NSC-34 cells was calculated.

Cell viability. Cell viability was assessed by double-labeling with fluorescein diacetate and propidium iodide (PI) (42). The assay is based on the ability of living cells to hydrolyze fluorescein diacetate (10 $\mu \mathrm{g} / \mathrm{ml}$ PBS, $5 \mathrm{~min}$; Sigma-Aldrich) using intracellular esterases, resulting in a green/yellow-colored fluorescence. Dead cells were labeled with PI (5 $\mu \mathrm{g} / \mathrm{ml}$ PBS, 5 min; Sigma-Aldrich), which interacts with DNA to produce a red fluorescence of cell nuclei. The analysis procedure was the same as described above for the BrdU assay.

For all assays, the respective mean values were analyzed using a non-parametric Kruskal-Wallis test and Dunn's multiple comparison test as post-hoc tests using Graph Pad Prism 4 software. $\mathrm{P} \leq 0.05$ was considered to indicate a statistically significant result. All experiments were independently performed in triplicate.

Semi-quantitative RT-PCR. Cells were harvested $24 \mathrm{~h}$ prior to OGD induction or LPS treatment. The mRNA expression levels were determined as described above for the spinal cord tissue sections. Five flasks were prepared for each treatment group (control, control + minocycline, OGD, OGD + minocycline, LPS and LPS + minocycline). The experiment was repeated in duplicate. Statistical analysis was performed with a non-parametric Kruskal-Wallis test and Dunn's multiple comparison test as post-hoc test using Graph Pad Prism 4 software. $\mathrm{P}<0.05$ was considered to indicate a statistically significant result.

Immunohistochemistry. At 5 DIV (24 h after OGD induction), the cell cultures were fixed for $30 \mathrm{~min}$ in $4 \%$ buffered PFA, and unspecific binding sites were blocked with $10 \%$ bovine serum albumin (BSA; Sigma-Aldrich) $/ 0.3 \%$ Triton X-100 in PBS for $1 \mathrm{~h}$. Subsequently, the cultures were incubated with the aforementioned primary antibodies: Anti-Bax (1:200), anti-caspase-3 (1:100), anti-Bcl-2 (1:1,000), anti-MHC I (1:100), anti-TNF- $\alpha$ (1:500), anti-MMP9 (1:100), anti-GAP-43 (1:500), anti-VEGF (1:500), and anti-ATF3 (1:200) co-stained with mouse monoclonal pan-NF $(1: 1,000)$ or with rabbit polyclonal anti- $\beta$-III-tubulin $(1: 1,000)$ at $7{ }^{\circ} \mathrm{C}$ overnight, followed by a wash with PBS, then incubation with the secondary antibodies goat anti-mouse Alexa 488 (1:500) and donkey anti-rabbit Cy3 (1:250) at room temperature for $3 \mathrm{~h}$. All antibodies were diluted in $10 \%$ BSA/0.3\% Triton in PBS. The specificity of the immunoreaction was controlled by the application of buffer instead of primary antibodies. Cell cultures were examined using a fluorescence microscope (AxioImager M1; Plan-Neofluar objective; 20/0.5). For each treatment group (control, control + minocycline, OGD, OGD + minocycline, LPS, LPS + minocycline) and staining type two dishes were examined, in total 108 dishes. The experiment was performed in duplicate.

\section{Results}

\section{Animal model}

Surgical outcome/macroscopic assessment. The surgical procedure was well tolerated and wounds healed well. The treatments were fatal to none of the animals. In the first two post-operative weeks, clinical signs of hyperalgesia or discomfort were observed. Compared with injured PBS-treated rats, the minocycline-treated animals demonstrated diminished peripheral nerve regeneration, as indicated by significantly lower axon counts in the distal stump when compared with PBS-treated animals. Functional outcome (response of animals to thermal stimuli and muscle weight ratio of the gastrocnemius muscle) has been previously described (25).

Microscopic assessment. Immunohistochemical assessment was performed at $5 \mathrm{DPI}$ as at this DPI the PCR revealed the most marked alterations (see below). At 5 DPI, the population of SMI311-expressing motorneurons of the contralateral and ipsilateral ventral horns $(\mathrm{VH})$ was equal in number, form and staining intensity (Fig. 1). Astroglia-specific GFAP (Fig. 1A) and microglia-specific IBA1 (Fig. 1B) were expressed in the contralateral $\mathrm{VH}$. In the ipsilateral side, a marked induction of both markers was evident (Fig. 1A and B). Microglia activation could also be demonstrated by cell morphology. The cells were altered from their ramified form, and became thicker and retracted their branches. Glia activation indicated ongoing neurodegenerative processes at the nerve fiber level, which was not yet evident from SMI311 staining. With regards to GFAP, treatment with minocycline was ineffective (Fig. 1A). However, microglia activity was decreased by minocycline, and this effect was more marked in the ipsilateral VH (Fig. 1B).

Semi-quantitative RT-PCR. In the spinal cord of untreated animals, all experimental genes were constitutively expressed. GAP-43 possessed the highest expression levels, which were increased at $\geq 7$ DPI. The expression levels of all other genes were significantly increased by sciatic nerve injury at 3 DPI. This increase in expression levels was evident $>5$ DPI. In the case of MMP9 a marked increase in expression levels was observed at 3 and 5 DPI. At 7 DPI, the expression levels of caspase-3, Bcl-2, ATF3, TNF- $\alpha$ and VEGF returned to levels similar to those of the control, and the expression levels of VEGF were already significantly reduced at 5 DPI. The expression levels of Bax, MHC I and MMP9 remained high at $\geq 14$ DPI. With the exception of MMP9, no significant differences were observed between ipsilateral and contralateral effects following nerve injury. At 5 DPI, MMP9 was 

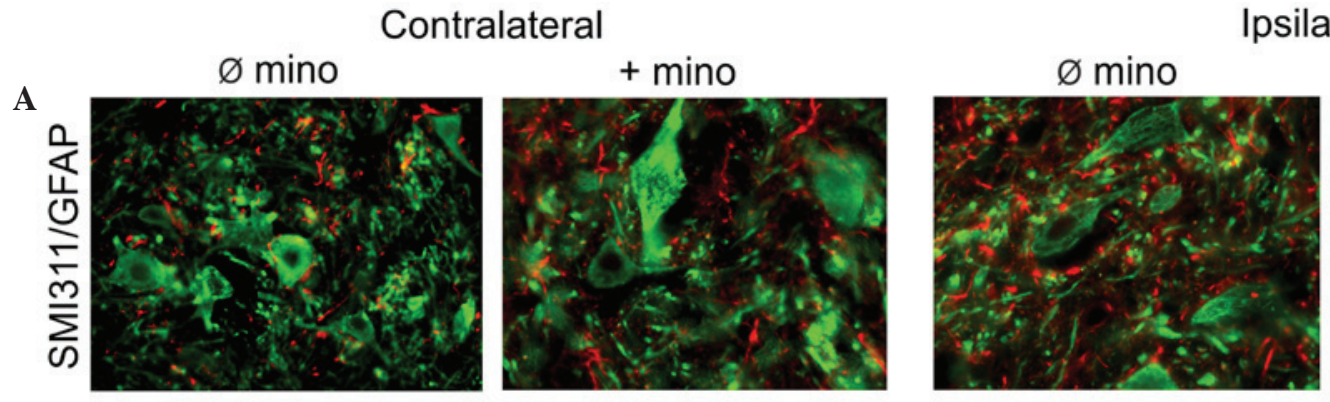

Ipsilateral

B
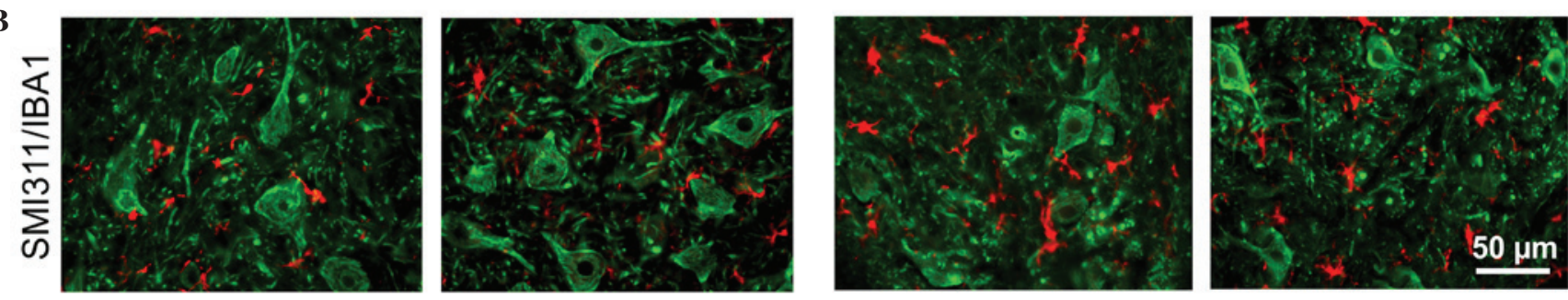

Figure 1. Representative fluorescence images of rat L4 and L5 ventral spinal cord sections at day 5 post-intervention. SMI311 immunofluorescence (green) shows a normal pattern of motorneurons in the contralateral and ipsilateral ventral horns. (A) GFAP-expressing astroglia (red). (B) IBA1-positive microglia cells (red). Ø mino, not treated with minocycline; + mino, treated with minocycline; GFAP, glial fibrillary acidic protein; IBA1, ionized calcium binding adaptor molecule 1 .

expressed at significantly higher levels on the ipsilateral side (Fig. 2).

Only the expression levels of certain genes were affected by minocycline. Treatment with minocycline reduced the ipsilateral expression levels of MHC I at 3 DPI. The expression levels of TNF- $\alpha$ were reduced ipsilaterally at 3 and 5 DPI. At 5 DPI, the contralateral expression levels of TNF- $\alpha$ were also diminished. Minocycline reduced the ipsilateral expression levels of MMP9 at 3 DPI and the contralateral expression levels at 5 DPI. Treatment with minocycline decreased the ipsilateral and contralateral expression levels of VEGF at 3 DPI. Furthermore, the nerve injury-induced expression of GAP-43 was significantly suppressed (Fig. 2).

Immunohistochemistry. The protein expression levels of the genes examined by PCR were evaluated by fluorescence immunohistochemistry at 5 DPI (Fig. 3). For caspase-3, no fluorescence signal was detected in the contralateral $\mathrm{VH}$ (Fig. 3A). Bax, Bcl-2, TNF- $\alpha$, MHC I, MMP9 (Fig. 3A), ATF3 and VEGF (Fig. 3B) were expressed in motorneurons of the contralateral $\mathrm{VH}$, although at relatively low levels. Only GAP-43 was markedly expressed, indicating synaptic contacts (Fig. 3A).

The majority of immunofluorescence signals were activated by unilateral nerve injury in the ipsilateral VH. In the case of $\mathrm{Bax}$, in addition to marked cytoplasmic staining of motorneurons, marked nuclear fluorescence was visible (Fig. 3A). Such injury/hypoxia-induced translocation of Bax to the nucleus has previously been described for neonatal neurons of the spinal cord (27) and brain (43). The enhanced motorneuronal signals of caspase-3 and Bcl-2 (Fig. 3A) were located in the cytoplasm, and $\mathrm{Bcl}-2$ was also markedly expressed in the contralateral VH motorneurons (Fig. 3A). Intense TNF- $\alpha$ staining was observed in the motorneuronal cytoplasm with compaction/concentration around and inside the nucleus (Fig. 3A). The markedly intense immunosignals of MHC I, MMP9 (Fig. 3A) and VEGF (Fig. 3B) were evenly distributed in the cytoplasm of the motorneurons. In addition, the expression of the ATF3 transcription factor was predominantly upregulated in the cytoplasm (Fig. 3B). A similar pattern with the majority of neurons exhibiting marked cytoplasmic staining and only a minority also exhibiting nuclear translocation was reported by Seijffers et al (44). GAP-43 immunostaining demonstrated a reduction in synaptic contacts (Fig. 3A).

The effect of minocycline was marginal. MHC I appeared to be upregulated by minocycline in the contralateral and ipsilateral VH motorneurons (Fig. 3A). Conversely, the injury-induced upregulation of VEGF was reversed by minocycline (Fig. 3B).

\section{Cell culture model}

Assessment of cell survival and proliferation. MTT, bromodeoxyuridine (BrdU) and vital staining were used to assess cellular survival and proliferation (Figs. 4 and 5). The MTT assay is based on the specific turnover of MTT to formazan, requiring viable cells. An increased extinction coefficient indicates an enhanced MTT turnover rate and thus a greater number of viable cells. The MTT assay demonstrated a significant $(\mathrm{P}<0.05)$ OGD-induced reduction of the metabolic activity of NSC-34 cells, whereas LPS had no effect on metabolic activity levels (Fig. 5A). Independent of treatment, minocycline did not alter the treatment group-specific MTT turnover (Fig. 5A).

In contrast to post-mitotic motorneurons, NSC-34 cells are able to proliferate as they are neuroblastoma-spinal cord hybrids. The basic mitotic index, determined by BrdU incorporation in the control group, was $48 \pm 5 \%$ (Figs. 4B and 5B). OGD significantly reduced the proliferation of NSC-34 cells $(\mathrm{P}<0.01)$; however, LPS was ineffective (Figs. 4B and 5B). Minocycline had no effect on NSC-34 cell proliferation, in either the control or the LPS group. In addition, minocycline was not able to reverse the inhibitory effect of OGD (Figs. 4B and 5B). 

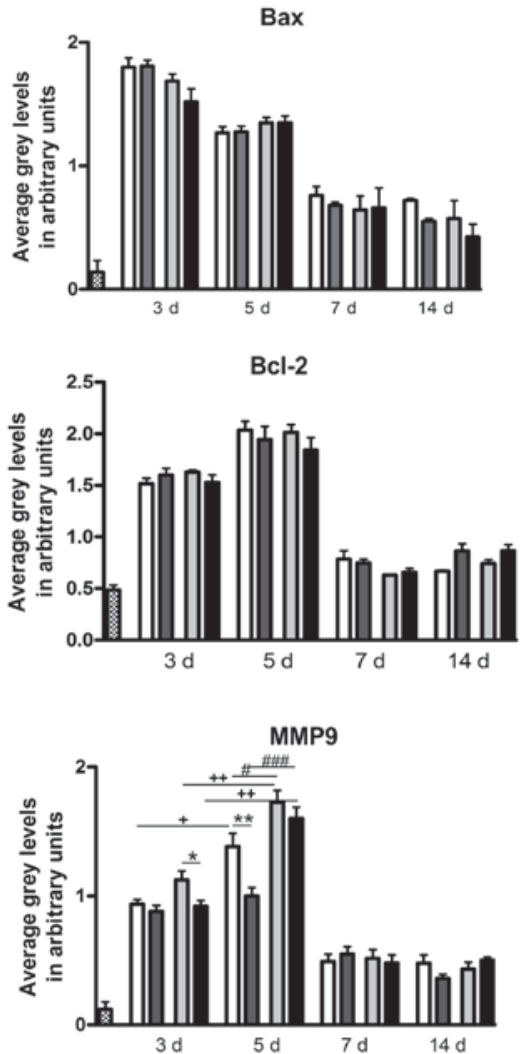

EDas Naive control
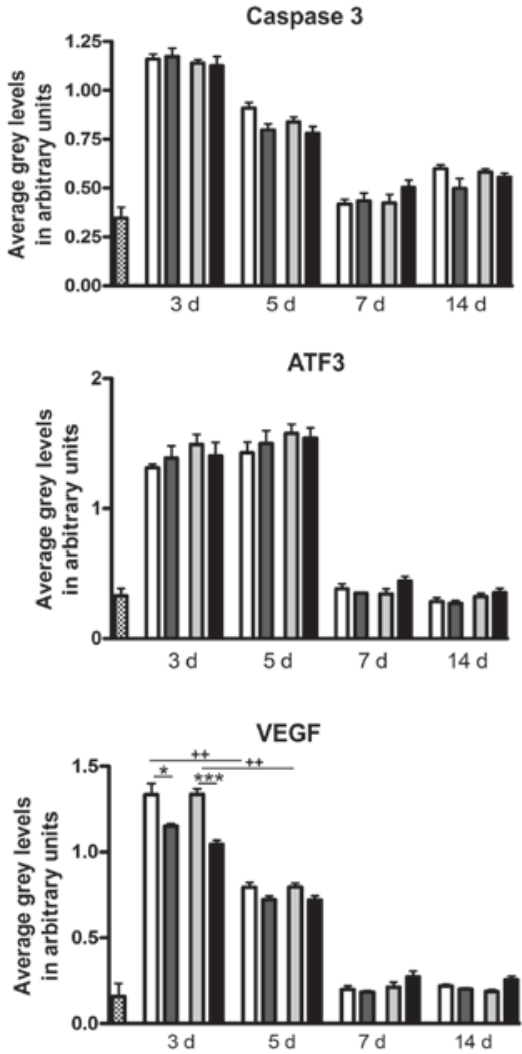

Contralateral, + mino
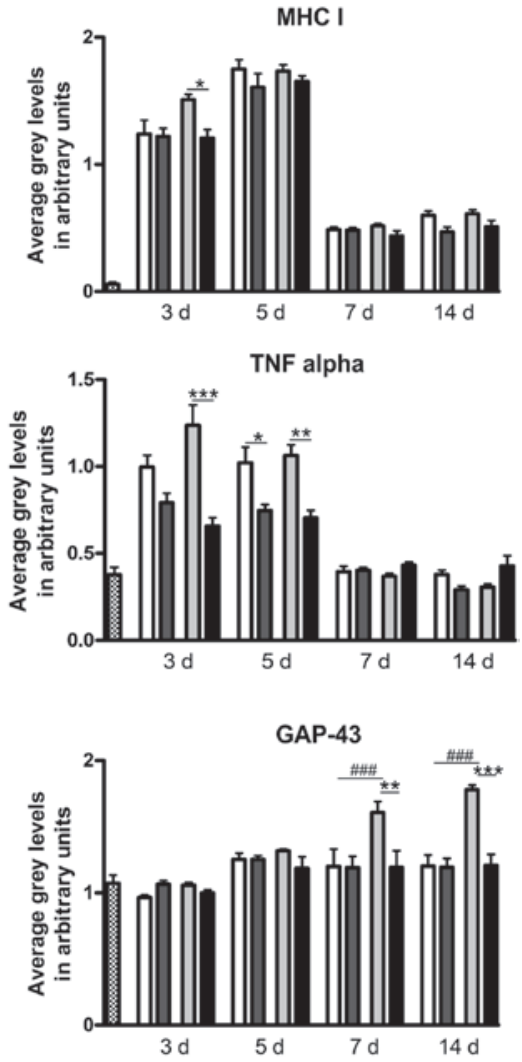

Ipsilateral, Ø mino

Figure 2. Semi-quantitative reverse transcription-polymerase chain reaction analysis of the mRNA expression levels of various genes in rat L3-L6 spinal cord

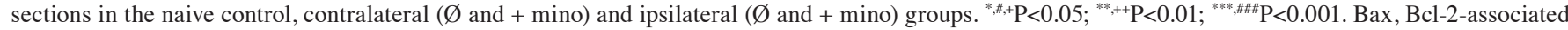
X protein; MHC I, major histocompatibility complex I; Bcl-2, B cell lymphoma 2; ATF3, activating transcription factor 3; TNF- $\alpha$, tumor necrosis factor- $\alpha$; MMP9, matrix metalloproteinase 9; VEGF, vascular endothelial growth factor; GAP-43, growth associated protein-43; D, days; $\varnothing$ mino, not treated with minocycline; + mino, treated with minocycline.

Vital staining of control cultures revealed only scattered dead (PI-positive) cells, which were not affected by minocycline (Figs. 4A and 5C). OGD induced significant neurotoxicity $(\mathrm{P}<0.001)$, while minocycline was marginally able to reverse this neurotoxicity $(\mathrm{P}<0.1$; Fig. 4A and $5 \mathrm{C})$. LPS alone or in combination with minocycline had no effect on NSC-34 cell viability (Fig. 4A and 5C).

Semi-quantitative RT-PCR. In untreated control NSC-34 cell cultures, all experimental genes were constitutively expressed, with low expression levels observed for ATF3, caspase-3 and VEGF. OGD was able to significantly increase the expression levels of Bcl-2 ( $\mathrm{P}<0.05)$, TNF- $\alpha(\mathrm{P}<0.01)$ and MMP9 $(\mathrm{P}<0.05)$. TNF- $\alpha$ and MMP9 were also significantly upregulated by LPS $(\mathrm{P}<0.05)$. Similarly to the results observed following the analysis of the tissue samples, the OGD stress-induced expression was significantly $(\mathrm{P}<0.05)$ suppressed by minocycline. Furthermore, minocycline also significantly reduced VEGF expression ( $\mathrm{P}<0.05$; Fig. 6).

Immunohistochemistry. The mRNA expression profile of NSC-34 cells was also investigated by fluorescence immunohistochemical evaluation of protein expression (Fig. 7). In untreated control cell cultures (Fig. 7A and B), all proteins were expressed endogenously. This result was expected as primary cell cultures are usually characterized by a low and constant cell death rate. The stressors OGD (Fig. 7A and B) and LPS (Fig. 7A and B) induced the activation of all proteins.
Minocycline had no effect on control cultures (Fig. 7A and B), but was able to reduce the stress-induced upregulation of TNF- $\alpha$ and MMP9 (Fig. 7A) expression. Combined with LPS, minocycline was able to inhibit VEGF expression (Fig. 7B). Conversely to in vivo experiments, the expression of Bax was predominantly located in the cytoplasm (Fig. 7A). Only in stressed and minocycline-treated cells was nuclear expression visible (Fig. 7A). The expression of transcription factor ATF3 was upregulated following stress and located in the nucleus (Fig. 7B), and this expression was inhibited by minocycline (Fig. 7B). Furthermore, the expression pattern of GAP-43 was different to those observed in vivo. Under all experimental conditions, fluorescence signals were present in the cytoplasm of NSC-34 cells, although not in the fibers (Fig. 7A).

\section{Discussion}

Transection of peripheral nerves induces a complex cascade of reactions, including retrograde processes targeting the axotomized spinal motorneurons. In neonatal rats, axotomized motorneurons often die $(45,46)$. However, in adult animals, degeneration of spinal motorneurons following peripheral nerve axotomy rarely occurs $(47,48)$. Only severe nerve ventral root avulsion has more severe effects and induces a significant loss of axotomized motorneurons in the respective spinal cord segments (49). In addition, less severely injured adult ipsilateral 


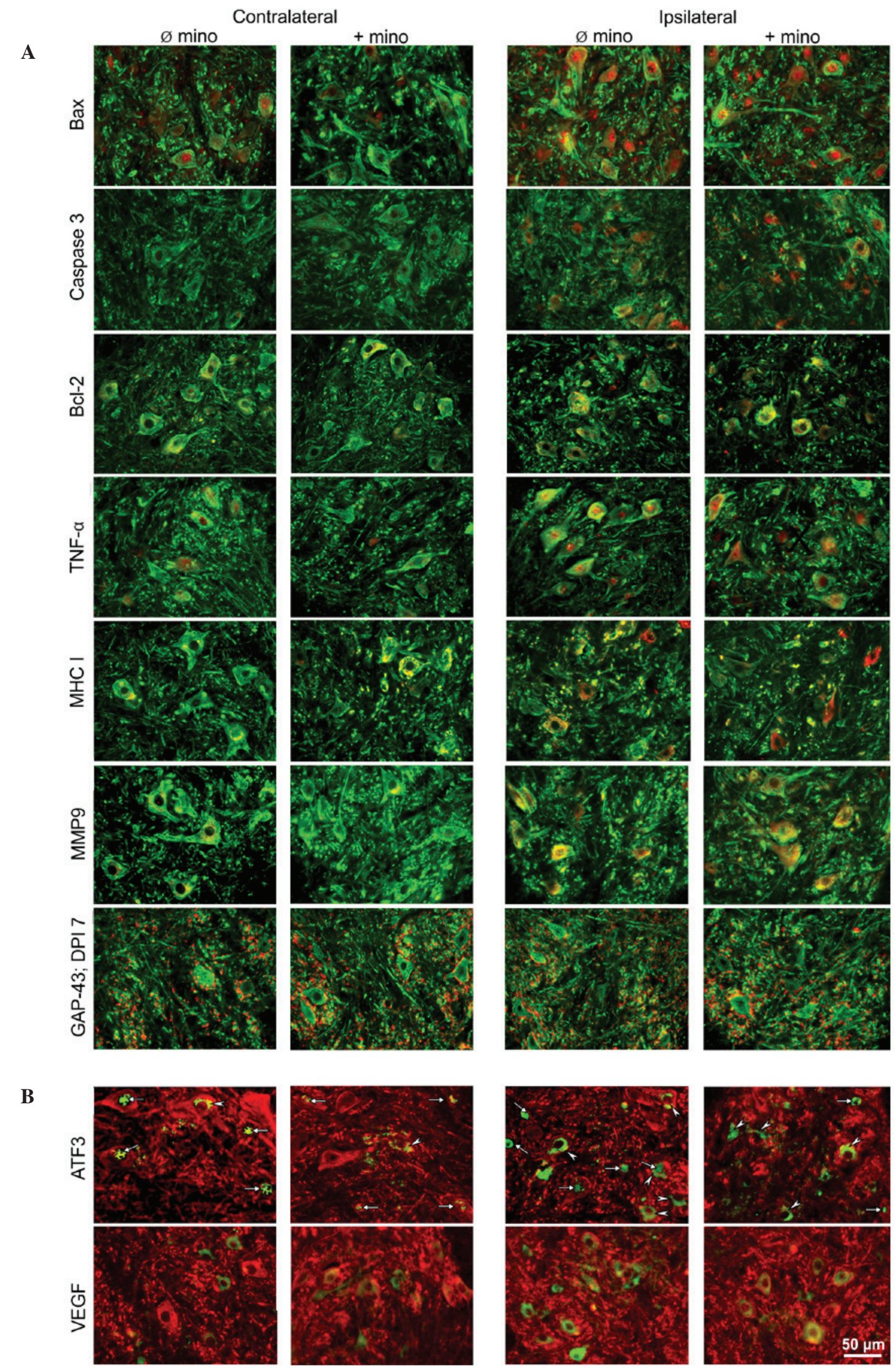

Figure 3. Representative fluorescence images of rat L4 and L5 ventral spinal cord sections at 5 DPI. (A) Tissue sections were double-immunostained with SMI311 (green staining, neuron-specific) and various antibodies (mentioned at the left, red staining), resulting in a combined yellow immunosignal. (B) Tissue sections were double-immunostained with $\beta$-III-tubulin (red staining, neuron-specific) and ATF3 or VEGF (green staining), resulting in a combined yellow immunosignal. Arrows indicate nuclear expression, arrowheads indicate cytoplasmic expression. $\varnothing$ mino, not treated with minocycline; + mino, treated with minocycline; Bax, Bcl-2-associated X protein; Bcl-2, B cell lymphoma 2; TNF- $\alpha$, tumor necrosis factor- $\alpha$; MHC I, major histocompatibility complex I; MMP9, matrix metalloproteinase 9; GAP-43, growth associated protein-43; DPI, days post-intervention; ATF3, activating transcription factor 3; VEGF, vascular endothelial growth factor. 


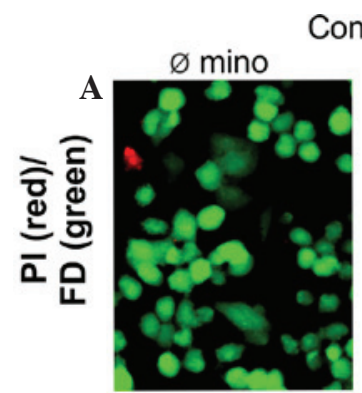

Control
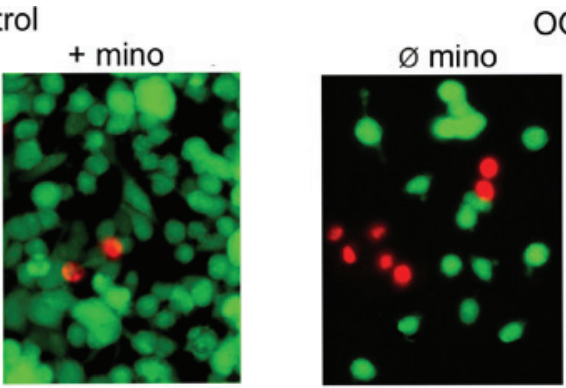

OGD
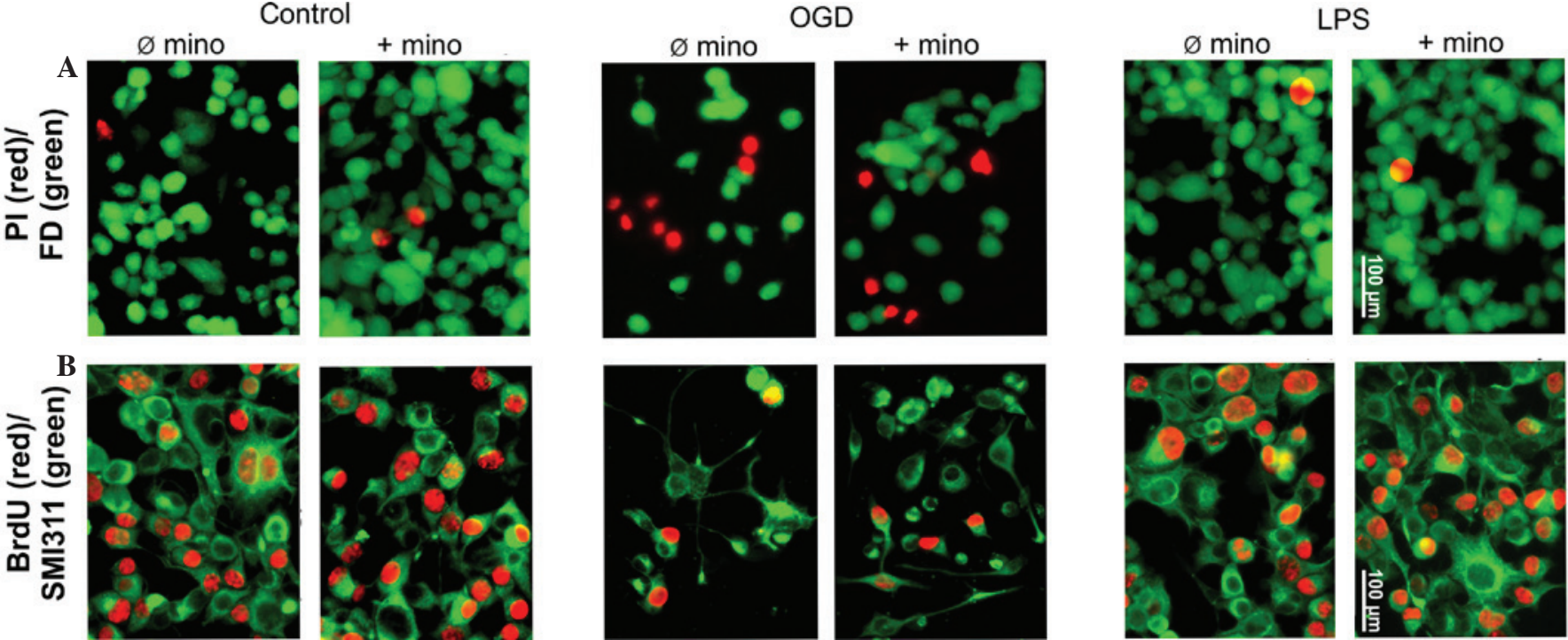

Figure 4. (A) Assessment of NSC-34 cell integrity by double-labeling with PI (red staining) and FD (green staining). (B) Assessment of NSC-34 cell mitotic index by BrdU incorporation and SMI311 (green staining, neuron-specific). $\varnothing$ mino, not treated with minocycline; + mino, treated with minocycline; OGD, oxygen glucose deprivation; LPS, lipopolysaccharide; PI, propidium iodide; FD, fluorescein diacetate; BrdU, bromodeoxyuridine.
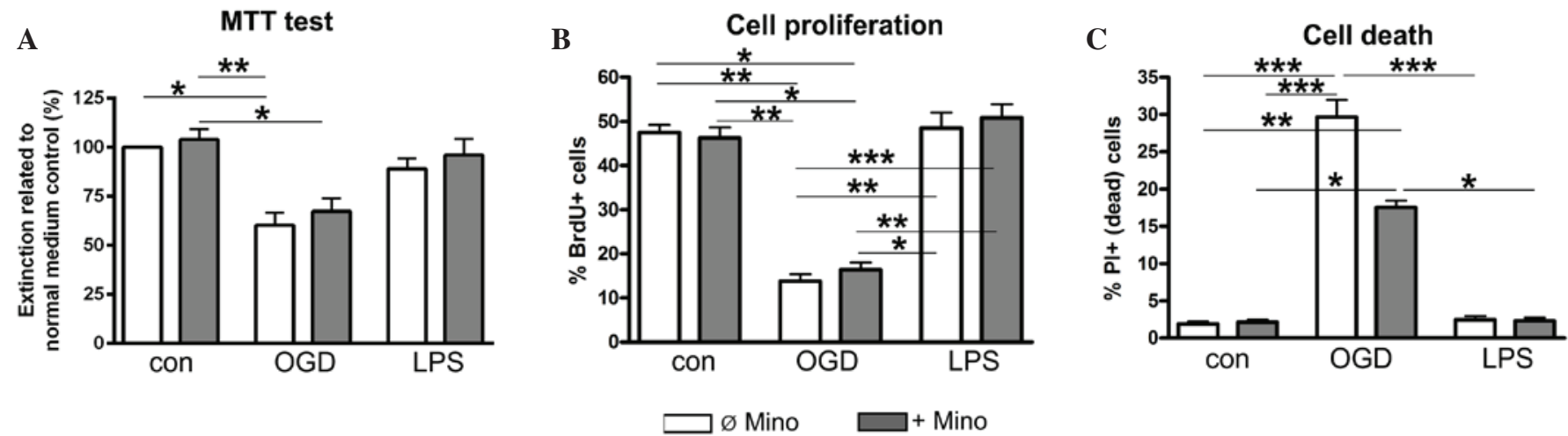

Figure 5. Respective quantitative analysis of (A) MTT, (B) BRdU and (C) PI assays. Data are presented as the mean \pm standard deviation; $\mathrm{n}=9$ cultures/group; for each culture, a mean of three vision fields/dish was used for calculations. ${ }^{*} \mathrm{P}<0.05 ;{ }^{* *} \mathrm{P}<0.01 ;{ }^{* * *} \mathrm{P}<0.001$. Con, control; OGD, oxygen glucose deprivation; LPS, lipopolysaccharide; PI, propidium iodide; BrdU, bromodeoxyuridine; $\varnothing$ mino, not treated with minocycline; + mino, treated with minocycline.

motorneurons develop classical post-traumatic signs, including synaptic terminal retraction (48). Furthermore, microglia activation is regularly observed $(50,51)$.

In the rat model of sciatic nerve reconstruction in the present study, a post-traumatic pattern in the $\mathrm{VH}$ was also observed. Motorneurons did not exhibit visible signs of neurodegeneration. Aside from that the sciatic nerve was reconstructed immediately following transection, which is neuroprotective (52). However, microglia activation and synaptic terminal retraction were detectable, and mRNA expression levels correlated with microglial activation. In the untreated spinal cord, all experimental genes were constitutively expressed at mRNA and protein levels. GAP-43, as a crucial component of the axon and presynaptic terminals exhibited, as expected, the highest expression levels. The genes and proteins involved in inflammation (MHC I, MMP9, TNF- $\alpha$ ), apoptosis (Bax, Bcl-2, caspase-3), or stress response (ATF3, VEGF) were expressed at basic levels. Sciatic nerve transection and reconstruction significantly increased the expression levels of these genes, although only in the first week. Similar time courses have been described previously, including those for Bax (53), ATF3 (54) and MHC I (55). The coincident but temporary upregulation of pro-apoptotic genes and proteins (Bax and caspase-3) or anti-apoptotic genes and proteins (Bcl-2), inflammation or stress demonstrated the presence of a self-defensive response to injury, and a conflict between injury-induced neurodegenerative signaling cascades and neuroprotective mechanisms during the acute phase following injury. In certain cases, this results in the survival and recovery of stressed motorneurons, as was observed in the present model of sciatic nerve reconstruction. In severe traumatic injuries, such as nerve avulsion, significant motorneuronal death occurred, accompanied by mitochondrial accumulation of Bax, cytochrome $c$ redistribution and activation of caspase-3 (29). Schwartz et al (56) termed this process a detrimental cost-benefit ratio; inflammation, being primarily a positive self-response eliminating or neutralizing injurious stimuli and restoring tissue integrity, exceeds the threshold of tolerability, and contributes to neuropathology. In this regard it appeared that the immune response to 

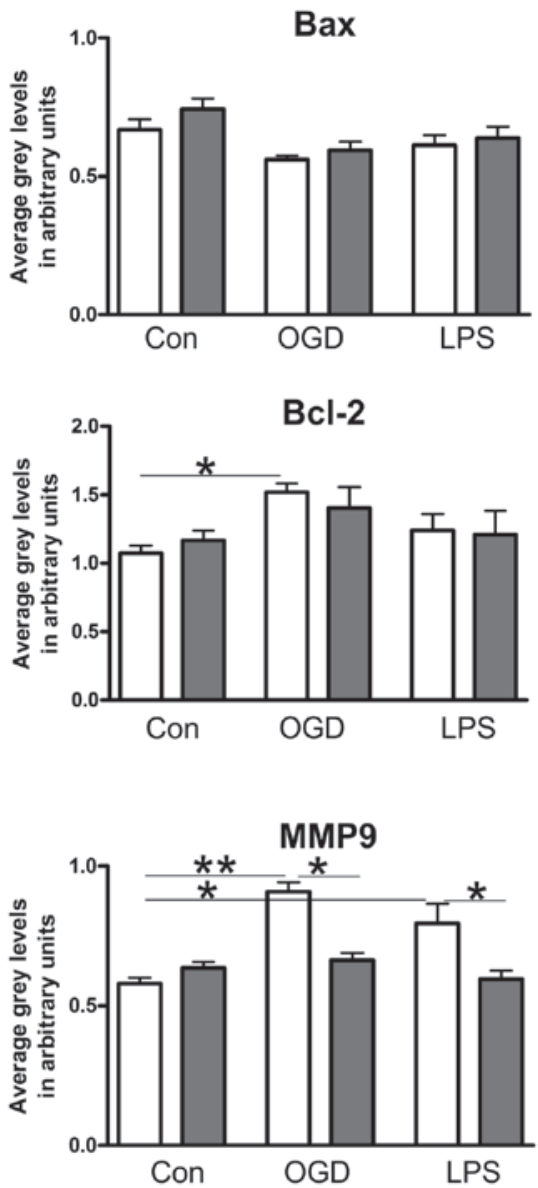

Caspase 3

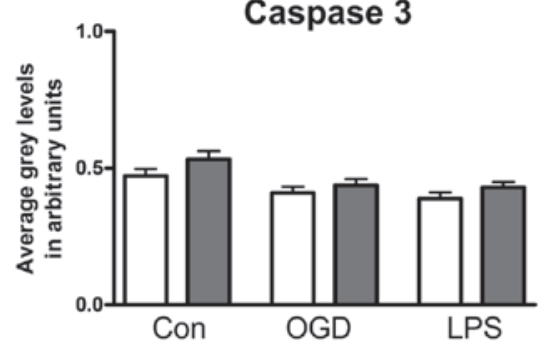

ATF3

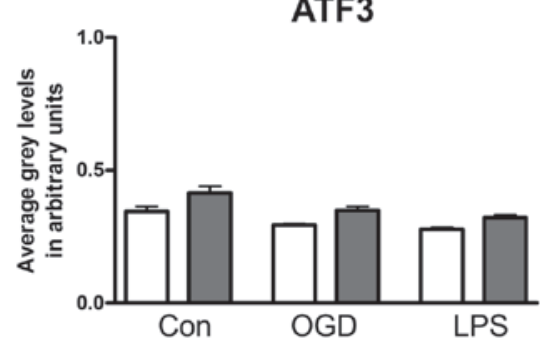

VEGF

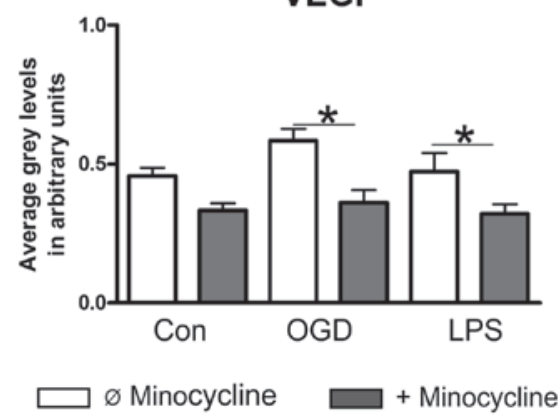

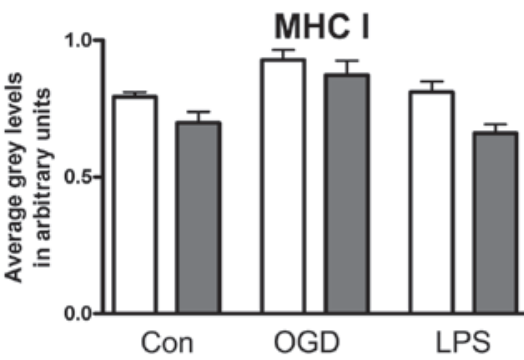
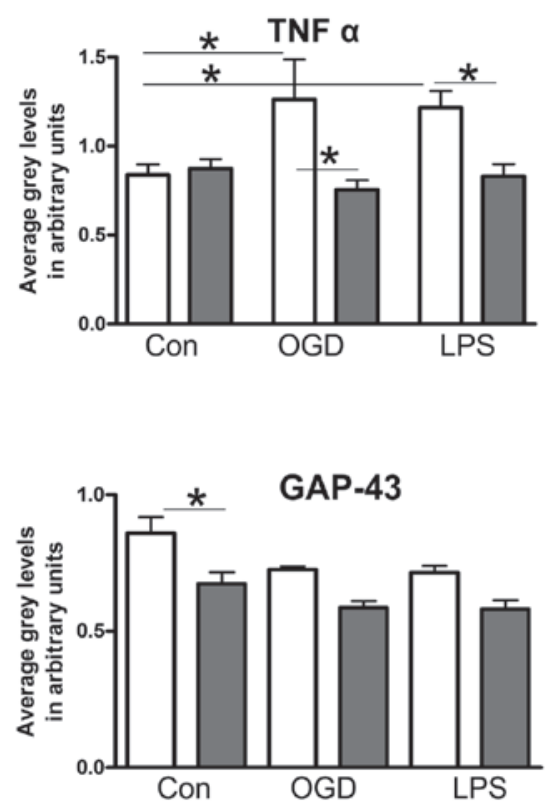

Figure 6. Semi-quantitative reverse transcription-polymerase chain reaction analysis of mRNA expression levels in NSC-34 cells in the con, OGD or LPS groups treated with or without minocycline. Data are presented as means \pm standard deviation; $\mathrm{n}=10$ flask/group. ${ }^{*} \mathrm{P}<0.05 ;{ }^{* *} \mathrm{P}<0.01$. Bax, Bcl-2-associated $\mathrm{X}$ protein; Con, control group; OGD, oral glucose deprivation; LPS, lipopolysaccharide; MHC I, major histocompatibility complex I; Bcl-2, B cell lymphoma 2; ATF3, activating transcription factor 3; TNF- $\alpha$, tumor necrosis factor- $\alpha$; MMP9, matrix metalloproteinase 9; VEGF, vascular endothelial growth factor; GAP-43, growth associated protein-43.

nerve injury in neonatal rats is reversed (57), thus offering one possible explanation for the aforementioned enhanced neuro-vulnerability in young animals.

Only MMP9 and GAP-43 demonstrated significantly increased ipsilateral induction compared with the contralateral side. All other genes reported no significant differences when the ipsilateral and contralateral sides were compared. The absence of ipsilateral vs. contralateral differences is in contrast to findings of Tang et al (58), which demonstrated that unilateral root-avulsion resulted in significant alterations to microRNA expression only in the ipsilateral spinal cord. However, the present results are in agreement with Rotshenker and Tal (59), who revealed that sprouting and synapse formation is enhanced by contralateral axotomy. Furthermore, there is evidence for transneuronal correspondence between ipsilateral and contralateral motorneurons. Transneuronal labeling of the L4 and L5 VH neurons following pseudorabies virus injection in the rat medial gastrocnemius muscle has been previously described (60). Neuropeptides, including peptide histidine isoleucine (61) and calcitonin gene-related peptide (CGRP) (62), were also induced bilaterally in rat spinal motor neurons following unilateral sciatic nerve transection. CGRP has been proposed to be involved in pain transmission and inflammation (63), as well as in repair mechanisms for neural regeneration following brachial plexus (2) or sciatic nerve (5) injury, in which its anti-apoptotic properties (64) were essential. These results are concordant with the hypothesis that unilateral sciatic nerve injury is able to induce bilateral stress and self-defense.

Synapse stripping is a regular result of peripheral axotomy, in which the extent of synaptic terminal retraction depends on the distance between motorneuron and lesion [it is lessened when the lesion side is further from the cell soma (65)], and on the severity of the lesion. This process occurs when neuronal cell death is not obvious (66). This remodeling has been suggested to be an adaptive mechanism of self-defense underlying enhanced neuronal viability $(67,68)$. Although the microglia activation demonstrated in the present study may be associated with synaptic stripping, a previous study suggested that the activation of glia is not correlated with the degree of synaptic stripping (65).

Numerous studies have demonstrated minocycline-induced neuroprotection (69-71). For axotomized motorneurons it influenced both the ipsilateral as well as the contralateral site (72). In the present investigation the effects of minocycline were relatively low, but did induce marginal inhibition 

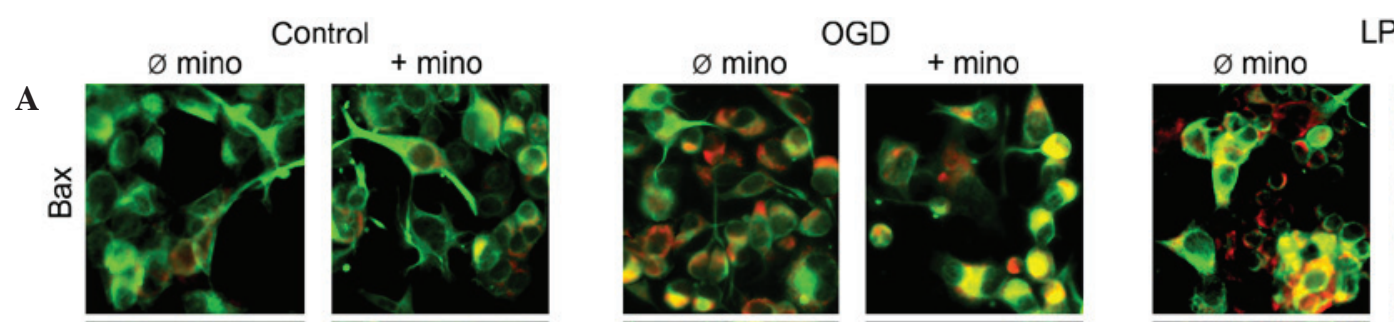

LPS
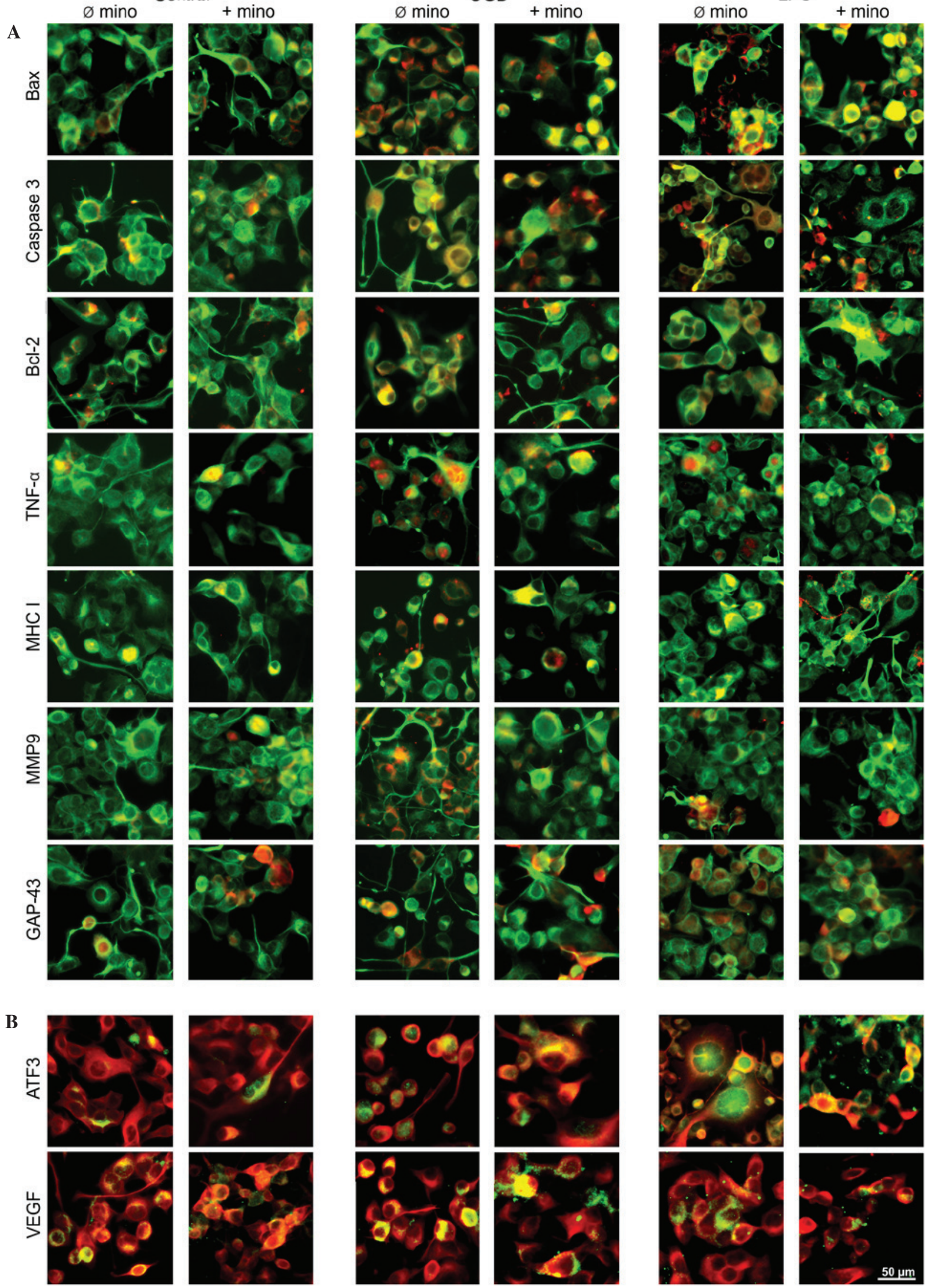

Figure 7. Representative fluorescence images of NSC-34 cells under various experimental conditions. (A) Cell cultures were double-immunostained with SMI311 (green staining) and various antibodies (red staining), often resulting in a combined yellow immunosignal. (B) Cell cultures were double-immunostained with $\beta$-III-tubulin (red staining) and ATF3 or VEGF (green staining), resulting in a combined yellow immunosignal. OGD, oxygen glucose deprivation; LPS, lipopolysaccharide; $\varnothing$ mino, not treated with minocycline; + mino, treated with minocycline; Bax, Bcl-2-associated X protein; Bcl-2, B cell lymphoma 2; TNF- $\alpha$, tumor necrosis factor- $\alpha$; MHC I, major histocompatibility complex I; MMP9, matrix metalloproteinase 9; GAP-43, growth associated protein-43; ATF3, activating transcription factor 3; VEGF, vascular endothelial growth factor. 
with a reduction in the expression levels of MMP9, TNF- $\alpha$, MHC I, VEGF and GAP-43. The inhibitory effects of minocycline have previously been described for MMP9 (73), MHC I (74), VEGF (75,76), TNF- $\alpha$ (77,78), and GAP-43 (79). One target of minocycline appears to be the transcription factor NF- $\kappa \mathrm{B}$. Minocycline has been demonstrated to inhibit the activation of NF- $\mathrm{B}$ (80), as well as its translocation into the cell nucleus (81). NF- $\kappa \mathrm{B}$ however induces the expression of MMP9 (82), MHC I (83) and VEGF (84). Furthermore, the activation of NF- $\kappa \mathrm{B}$ culminates in the release of TNF- $\alpha$ (85), which is a potent activator of $\mathrm{NF}-\kappa \mathrm{B}(86)$, thus an escalation of the minocycline effects can be assumed.

A late induction of motorneuronal GAP-43 expression following sciatic nerve injury has been previously demonstrated (87). GAP-43 is widely used as a marker for the growth/regeneration state of motorneurons, including synapse reconstruction, referred to as the 'cell body response' (88). The expression of GAP-43 requires acetylated p53 (89). However, minocycline is able to downregulate the expression of p53 (90) and to inhibit acetylation (91), which results in the minocycline-induced downregulation of GAP-43 expression demonstrated by the results of the present study.

Minocycline is able to downregulate or upregulate Bax and $\mathrm{Bcl}-2$, respectively, thereby resulting in an anti-apoptotic ratio (76,92-94). However, the present study did not demonstrate any significant minocycline effects on Bax or Bcl-2. These non-concordant results may be due to the heterogeneity of the models and minocycline treatment regimes. Matsukawa et al (95) demonstrated that minocycline attenuates experimentally-induced ischemic cell death by upregulating Bcl-2 expression at low doses. However, high minocycline doses exacerbated ischemic injury and reduced the number of Bcl-2-expressing neurons. Furthermore, minocycline targeted neurons alone, not astrocytes (95). The present results of the PCR analysis on the spinal cord tissue samples revealed the expression pattern of all spinal cord cell types including glial cells. Experiments were conducted using the NSC-34 motorneuronal-like cell line.

OGD, but not LPS, was highly toxic for NSC-34 cells and minocycline reduced the OGD-induced cell death rate, although these results were not significant $(\mathrm{P}>0.05)$. Notably, stress-induced changes in apoptosis-associated Bax and caspase-3 expression were not observed. These results were concordant with an in vivo study that demonstrated that dying lumbar motorneurons did not always exhibit apoptotic morphology (96). There is also evidence that NSC-34 cells expressed the apoptotic markers only under specific conditions (97). NSC-34 cell death could be induced by various apoptotic agents, and when intracellular protein inclusions containing mutant SOD1 existed, dispersed SOD1 prevented NSC-34 cells from apoptotic cell death (98). This may explain the observed apoptotic death of NSC-34 cells following $\mathrm{H}_{2} \mathrm{O}_{2}$-induced oxidative stress (99), as oxidative stress induced SOD1 aggregation (100). The absence of Bax, caspase-3, MHC I and ATF3 activation in NSC-34 cells suggested that motorneurons were not preferentially or even solely responsible for the nerve injury-mediated upregulation of these genes. PCR analysis demonstrated the expression pattern of neurons and glial cells, and the expression and stress-mediated regulation of these genes has been well-described: Astroglial Bax and caspase-3 (101); MHC I (102); ATF3 (103); microglial Bax and caspase-3 (104); MHC I (105); ATF3 (34); oligodendroglial Bax and caspase-3 (106); MHC I (107); and ATF3 (108). The absence of GAP-43 activation in NSC-34 cells may be a result of the in vitro absence of retrograde signals, which in vivo originate from the distal nerve stump and the disconnected nerve targets to initiate and support axonal regeneration (109).

TNF- $\alpha$ and VEGF induced the expression of MMP9; however, only OGD induced the expression of Bcl-2, and was able to parallelize the activating potency of sciatic nerve reconstruction. These results suggested that the expression level changes observed in vivo may be induced by motorneurons. However, the involvement of glia cells cannot be excluded. The glial expression of the four genes has previously been described: MMP9 (110,111); TNF- $\alpha$ (112); VEGF $(113,114)$; and Bcl-2 (92,115).

In NSC-34 cells minocycline exhibits inhibitory effects, whereby the above-mentioned $\mathrm{NF}-\kappa \mathrm{B}$ signaling pathway may be accepted due to the fact that NF- $\mathrm{BB}$ is expressed by NSC-34 cells, and activated and translocated into the nucleus as a result of cell stress $(116,117)$.

The present study demonstrated a massive but temporary SNR-mediated upregulation of all studied genes in L3-L6 sections of the spinal cord that was moderately affected by minocycline. The results observed within NSC-34 cells indicate that motorneurons are not significantly or solely responsible for these SNR-mediated changes in gene expression. To further clarify the cell-specific gene profiles, a more complex model of organotypic cell cultures may be a helpful alternative. This model could mimic tissue architecture of the spinal cord, which would allow an understanding of cellular etiology of these processes.

\section{Acknowledgements}

The authors of the present study are grateful to Ms. Leona Bück for technical assistance.

\section{References}

1. Oliveira AL, Risling M, Deckner M, Lindholm T, Langone F and Cullheim S: Neonatal sciatic nerve transection induces TUNEL labeling of neurons in the rat spinal cord and DRG. Neuroreport 8: 2837-2840, 1997.

2. Chen LJ, Ren YH, Liu L, Zhang XQ, Zhao Y, Wu WT and Li F: Upregulated expression of GAP-43 mRNA and protein in anterior horn motoneurons of the spinal cord after brachial plexus injury. Arch Med Res 41: 513-538, 2010.

3. Arocho LC, Figueroa JD, Torrado AI, Santiago JM, Vera AE and Miranda JD: Expression profile and role of EphrinA1 ligand after spinal cord injury. Cell Mol Neurobiol 31: 1057-1069, 2011.

4. Kobbert $\mathrm{C}$ and Thanos S: Topographic representation of the sciatic nerve motor neurons in the spinal cord of the adult rat correlates to region-specific activation patterns of microglia. J Neurocytol 29: 271-283, 2000.

5. Zheng LF, Wang R, Xu YZ, Yi XN, Zhang JW and Zeng ZC: Calcitonin gene-related peptide dynamics in rat dorsal root ganglia and spinal cord following different sciatic nerve injuries. Brain Res 1187: 20-32, 2008.

6. Wu F, Miao X, Chen J, Sun Y, Liu Z, Tao Y and Yu W: Down-regulation of GAP-43 by inhibition of caspases-3 in a rat model of neuropathic pain. Int J Clin Exp Pathol 5: 948-955, 2012.

7. Terenghi G, Hart A and Wiberg M: The nerve injury and the dying neurons: Diagnosis and prevention. J Hand Surg Eur Vol 36: 730-734, 2011. 
8. Amantea D and Bagetta G: Drug repurposing for immune modulation in acute ischemic stroke. Curr Opin Pharmacol 26: 124-130, 2015.

9. Smilack JD: The tetracyclines. Mayo Clin Proc 74: 727-729, 1999.

10. Yrjanheikki J, Tikka T, Keinänen R, Goldsteins G, Chan PH and Koistinaho J: A tetracycline derivative, minocycline, reduces inflammation and protects against focal cerebral ischemia with a wide therapeutic window. Proc Natl Acad Sci USA 96: 13496-13500, 1999.

11. Xu L, Fagan SC, Waller JL, Edwards D, Borlongan CV, Zheng J, Hill WD, Feuerstein G and Hess DC: Low dose intravenous minocycline is neuroprotective after middle cerebral artery occlusion-reperfusion in rats. BMC Neurol 4: 7, 2004.

12. Chen SD, Yin JH, Hwang CS, Tang CM and Yang DI: Anti-apoptotic and anti-oxidative mechanisms of minocycline against sphingomyelinase/ceramide neurotoxicity: Implication in Alzheimer's disease and cerebral ischemia. Free Radic Res 46: 340-350, 2012.

13. Hodl AK and Bonelli RM: Huntington's disease and minocycline. Mov Disord 20: 510-511, 2005.

14. Zemke D and Majid A: The potential of minocycline for neuroprotection in human neurologic disease. Clin Neuropharmacol 27: 293-298, 2004.

15. Pontieri FE, Ricci A, Pellicano C, Benincasa D and Buttarelli FR: Minocycline in amyotrophic lateral sclerosis: A pilot study. Neurol Sci 26: 285-287, 2005.

16. Giuliani F, Fu SA, Metz LM and Yong VW: Effective combination of minocycline and interferon-beta in a model of multiple sclerosis. J Neuroimmunol 165: 83-91, 2005.

17. Wells JE, Hurlbert RJ, Fehlings MG and Yong VW: Neuroprotection by minocycline facilitates significant recovery from spinal cord injury in mice. Brain 126 1628-1637, 2003.

18. Monaco EA 3rd, Weiner GM and Friedlander RM Randomized-controlled trial of minocycline for spinal cord injury shows promise. Neurosurgery 72: N17-19, 2013.

19. Stirling DP, Koochesfahani KM, Steeves JD and Tetzlaff W: Minocycline as a neuroprotective agent. Neuroscientist 11: 308-322, 2005.

20. Diguet E, Gross CE, Tison F and Bezard E: Rise and fall of minocycline in neuroprotection: Need to promote publication of negative results. Exp Neurol 189: 1-4, 2004.

21. Tsuji M, Wilson MA, Lange MS and Johnston MV: Minocycline worsens hypoxic-ischemic brain injury in a neonatal mouse model. Exp Neurol 189: 58-65, 2004.

22. Pinzon A, Marcillo A, Quintana A, Stamler S, Bunge MB, Bramlett HM and Dietrich WD: A re-assessment of minocycline as a neuroprotective agent in a rat spinal cord contusion model Brain Res 1243: 146-151, 2008.

23. Lee JH, Tigchelaar S, Liu J, Stammers AM, Streijger F, Tetzlaff W and Kwon BK: Lack of neuroprotective effects of simvastatin and minocycline in a model of cervical spinal cord injury. Exp Neurol 225: 219-230, 2010

24. Pinkernelle J, Fansa H, Ebmeyer U and Keilhoff G: Prolonged minocycline treatment impairs motor neuronal survival and glial function in organotypic rat spinal cord cultures. PloS One 8 : e73422, 2013

25. Keilhoff G, Langnaese K, Wolf G and Fansa H: Inhibiting effect of minocycline on the regeneration of peripheral nerves. Dev Neurobiol 67: 1382-1395, 2007.

26. Cashman NR, Durham HD, Blusztajn JK, Oda K, Tabira T, Shaw IT, Dahrouge S and Antel JP: Neuroblastoma x spinal cord (NSC) hybrid cell lines resemble developing motor neurons. Dev Dyn 194: 209-221, 1992.

27. Tiraihi T and Rezaie MJ: Apoptosis onset and bax protein distribution in spinal motoneurons of newborn rats following sciatic nerve axotomy. Int J Neurosci 113: 1163-1175, 2003.

28. Zhao W, Zhao Q, Liu J, Xu XY, Sun WW, Zhou X, Liu S and Wang TH: Electro-acupuncture reduces neuronal apoptosis linked to Bax and $\mathrm{Bcl}-2$ expression in the spinal cords of cats subjected to partial dorsal root ganglionectomy. Neurochem Res 33: 2214-2221, 2008.

29. Martin LJ and Liu Z: Injury-induced spinal motor neuron apoptosis is preceded by DNA single-strand breaks and is p53and Bax-dependent. J Neurobiol 50: 181-197, 2002.

30. Lu XM, Shu YH, Qiu CH, Chen KT and Wang YT: Protective effects and anti-apoptotic role of nerve growth factor on spinal cord neurons in sciatic nerve-injured rats. Neurol Res 36: $814-823,2014$
31. Payés AC, Zanon RG, Pierucci A and Oliveira AL: MHC class I upregulation is not sufficient to rescue neonatal alpha motoneurons after peripheral axotomy. Brain Res 1238: 23-30, 2008.

32. Ohtori S, Takahashi K, Moriya H and Myers RR: TNF-alpha and TNF-alpha receptor type 1 upregulation in glia and neurons after peripheral nerve injury: Studies in murine DRG and spinal cord. Spine (Phila Pa 1976) 29: 1082-1088, 2004.

33. Lindå $\mathrm{H}$, Sköld $\mathrm{MK}$ and Ochsmann T: Activating transcription factor 3, a useful marker for regenerative response after nerve root injury. Front Neurol 2: 30, 2011

34. Hunt D, Raivich G and Anderson PN: Activating transcription factor 3 and the nervous system. Front Mol Neurosci 5: 7, 2012.

35. Fu CY, Hong GX and Wang FB: Expression of vascular endothelial growth factor and its fetal liver kinase-1 receptor in spinal cord and dorsal root ganglia after neurotomy of sciatic nerve in rats. Chin J Traumatol 8: 17-22, 2005

36. Liou JT, Sum DC, Liu FC, Mao CC, Lai YS and Day YJ: Spatial and temporal analysis of nociception-related spinal cord matrix metalloproteinase expression in a murine neuropathic pain model. J Chin Med Assoc 76: 201-110, 2013.

37. Jacobson RD, Virág I and Skene JH: A protein associated with axon growth, GAP-43, is widely distributed and developmentally regulated in rat CNS. J Neurosci 6: 1843-1855, 1986.

38. Bulsara KR, Iskandar BJ, Villavicencio AT and Skene JH: A new millenium for spinal cord regeneration: Growth-associated genes. Spine (Phila Pa 1976) 27: 1946-1949, 2002.

39. Raghavendra V, Tanga F and DeLeo JA: Inhibition of microglial activation attenuates the development but not existing hypersensitivity in a rat model of neuropathy. J Pharmacol Exp Ther 306: 624-630, 2003

40. Langnaese K, John R, Schweizer H, Ebmeyer U and Keilhoff G: Selection of reference genes for quantitative real-time PCR in a rat asphyxial cardiac arrest model. BMC Mol Biol 9: 53, 2008.

41. Lucas B, Pinkernelle J, Fansa H and Keilhoff G: Effects of cerebrolysin on rat Schwann cells in vitro. Acta Histochem 116: 820-830, 2014.

42. Keilhoff G and Wolf G: Comparison of double fluorescence staining and LDH-test for monitoring cell viability in vitro. Neuroreport 5: 129-132, 1993.

43. Infante SK, Oberhauser AF and Perez-Polo JR: Bax phosphorylation association with nucleus and oligomerization after neonatal hypoxia-ischemia. J Neurosci Res 91: 1152-1164, 2013.

44. Seijffers R, Mills CD and Woolf CJ: ATF3 increases the intrinsic growth state of DRG neurons to enhance peripheral nerve regeneration. J Neurosci 27: 7911-7920, 2007.

45. Wolff JR and Missler M: Synaptic reorganization in developing and adult nervous systems. Ann Anat 174: 393-403, 1992

46. Vieira AS, de Rezende AC and Rogerio F: Evaluating motor neuron death in neonatal rats subjected to sciatic nerve lesion. Methods Mol Biol 846: 383-391, 2012.

47. Carlson J, Lais AC and Dyck PJ: Axonal atrophy from permanent peripheral axotomy in adult cat. J Neuropathol Exp Neurol 38: $579-585,1979$.

48. Victório SC, Havton LA and Oliveira AL: Absence of IFN $\gamma$ expression induces neuronal degeneration in the spinal cord of adult mice. J Neuroinflammation 7: 77, 2010.

49. Ohlsson M, Nieto JH, Christe KL and Havton LA: Long-term effects of a lumbosacral ventral root avulsion injury on axotomized motor neurons and avulsed ventral roots in a non-human primate model of cauda equina injury. Neuroscience 250: 129-139, 2013.

50. Chen T, Koga K, Li XY and Zhuo M: Spinal microglial motility is independent of neuronal activity and plasticity in adult mice. Mol Pain 6: 19, 2010.

51. Chew DJ, Carlstedt T and Shortland PJ: A comparative histological analysis of two models of nerve root avulsion injury in the adult rat. Neuropathol Appl Neurobiol 37: 613-632, 2011.

52. Hart AM, Terenghi G and Wiberg M: Neuronal death after peripheral nerve injury and experimental strategies for neuroprotection. Neurol Res 30: 999-1011, 2008.

53. Gillardon F, Klimaschewski L, Wickert H, Krajewski S, Reed JC and Zimmermann M: Expression pattern of candidate cell death effector proteins Bax, Bcl-2, Bcl-X and c-Jun in sensory and motor neurons following sciatic nerve transection in the rat. Brain Res 739: 244-250, 1996.

54. Tsujino H, Kondo E, Fukuoka T, Dai Y, Tokunaga A, Miki K, Yonenobu K, Ochi T and Noguchi K: Activating transcription factor 3 (ATF3) induction by axotomy in sensory and motoneurons: A novel neuronal marker of nerve injury. Mol Cell Neurosci 15: 170-182, 2000. 
55. Sabha M Jr, Emirandetti A, Cullheim S and De Oliveira AL: MHC I expression and synaptic plasticity in different mice strains after axotomy. Synapse 62: 137-148, 2008.

56. Schwartz M, Butovsky O, Brück W and Hanisch UK: Microglial phenotype: Is the commitment reversible? Trends Neurosci 29: 68-74, 2006.

57. Vega-Avelaira D, Moss A and Fitzgerald M: Age-related changes in the spinal cord microglial and astrocytic response profile to nerve injury. Brain Behav Immun 21: 617-623, 2007.

58. Tang Y, Ling ZM, Fu R, Li YQ, Cheng X, Song FH, Luo HX and Zhou LH: Time-specific microRNA changes during spinal motoneuron degeneration in adult rats following unilateral brachial plexus root avulsion: Ipsilateral vs. contralateral changes. BMC Neurosci 15: 92, 2014

59. Rotshenker $\mathrm{S}$ and Tal M: The transneuronal induction of sprouting and synapse formation in intact mouse muscles. J Physiol 360: 387-396, 1985

60. Rotto-Percelay DM, Wheeler JG, Osorio FA, Platt KB and Loewy AD: Transneuronal labeling of spinal interneurons and sympathetic preganglionic neurons after pseudorabies virus injections in the rat medial gastrocnemius muscle. Brain Res 574: 291-306, 1992.

61. Villar MJ, Cortés R, Theodorsson E, Wiesenfeld-Hallin Z, Schalling M, Fahrenkrug J, Emson PC and Hökfelt T: Neuropeptide expression in rat dorsal root ganglion cells and spinal cord after peripheral nerve injury with special reference to galanin. Neuroscience 33: 587-604, 1989.

62. Piehl F, Arvidsson U, Johnson H, Cullheim S, Villar M, Dagerlind A, Terenius L, Hökfelt T and Ulfhake B: Calcitonin Gene-related Peptide (CGRP)-like Immunoreactivity and CGRP mRNA in rat spinal cord motoneurons after different types of lesions. Eur J Neurosci 3: 737-757, 1991.

63. Benemei S, Nicoletti P, Capone JG and Geppetti P: CGRP receptors in the control of pain and inflammation. Curr Opin Pharmacol 9: 9-14, 2009.

64. Sueur S, Pesant M, Rochette L and Connat JL: Antiapoptotic effect of calcitonin gene-related peptide on oxidative stress-induced injury in $\mathrm{H} 9 \mathrm{c} 2$ cardiomyocytes via the RAMP1/CRLR complex. J Mol Cell Cardiol 39: 955-963, 2005.

65. Spejo AB and Oliveira AL: Synaptic rearrangement following axonal injury: Old and new players. Neuropharmacology 96 : $113-123,2015$.

66. Guntinas-Lichius O, Neiss WF, Gunkel A and Stennert E: Differences in glial, synaptic and motoneuron responses in the facial nucleus of the rat brainstem following facial nerve resection and nerve suture reanastomosis. Eur Arch Otorhinolaryngol 251: 410-417, 1994.

67. Hardingham GE: Coupling of the NMDA receptor to neuroprotective and neurodestructive events. Biochem Soc Trans 37: 1147-1160, 2009.

68. Tyzack GE, Sitnikov S, Barson D, Adams-Carr KL, Lau NK, Kwok JC, Zhao C, Franklin RJ, Karadottir RT, Fawcett JW and Lakatos A: Astrocyte response to motor neuron injury promotes structural synaptic plasticity via STAT3-regulated TSP-1 expression. Nat Commun 5: 4294, 2014

69. Garrido-Mesa N, Zarzuelo A and Gálvez J: Minocycline: Far beyond an antibiotic. Br J Pharmacol 169: 337-352, 2013.

70. Liao TV, Forehand CC, Hess DC and Fagan SC: Minocycline repurposing in critical illness: Focus on stroke. Curr Top Med Chem 13: 2283-2290, 2013.

71. Li C, Yuan K and Schluesener H: Impact of minocycline on neurodegenerative diseases in rodents: A meta-analysis. Rev Neurosci 24: 553-562, 2013

72. Teng YD, Choi H, Onario RC, Zhu S, Desilets FC, Lan S, Woodard EJ, Snyder EY, Eichler ME and Friedlander RM Minocycline inhibits contusion-triggered mitochondrial cytochrome c release and mitigates functional deficits after spinal cord injury. Proc Natl Acad Sci USA 101: 3071-3076, 2004.

73. Chaturvedi M and Kaczmarek L: Mmp-9 inhibition: A therapeutic strategy in ischemic stroke. Mol Neurobiol 49: 563-673, 2014.

74. Enose-Akahata Y, Matsuura E, Tanaka Y, Oh U and Jacobson S: Minocycline modulates antigen-specific CTL activity through inactivation of mononuclear phagocytes in patients with HTLV-I associated neurologic disease. Retrovirology 9: 16, 2012.

75. Jung HJ, Seo I, Jha BK, Suh SI, Suh MH and Baek WK: Minocycline inhibits angiogenesis in vitro through the translational suppression of HIF-1 $\alpha$. Arch Biochem Biophys 545: $74-82,2014$
76. Li CH, Liao PL, Yang YT, Huang SH, Lin CH, Cheng YW and Kang JJ: Minocycline accelerates hypoxia-inducible factor-1 alpha degradation and inhibits hypoxia-induced neovasculogenesis through prolyl hydroxylase, von Hippel-Lindau-dependent pathway. Arch Toxicol 88: 659-671, 2014.

77. Sun C, Li XX, He XJ, Zhang Q and Tao Y: Neuroprotective effect of minocycline in a rat model of branch retinal vein occlusion. Exp Eye Res 113: 105-116, 2013.

78. Levkovitz Y, Fenchel D, Kaplan Z, Zohar J and Cohen H: Early post-stressor intervention with minocycline, a second-generation tetracycline, attenuates post-traumatic stress response in an animal model of PTSD. Eur Neuropsychopharmacol 25: $124-132,2015$

79. Kwon MJ, Kim J, Shin H, Jeong SR, Kang YM, Choi JY, Hwang DH and Kim BG: Contribution of macrophages to enhanced regenerative capacity of dorsal root ganglia sensory neurons by conditioning injury. J Neurosci 33: 15095-15108, 2013.

80. Ataie-Kachoie P, Badar S, Morris DL and Pourgholami MH: Minocycline targets the NF-kB Nexus through suppression of TGF- $\beta 1-T A K 1-I k B$ signaling in ovarian cancer. Mol Cancer Res 11: 1279-1291, 2013.

81. Pang T, Wang J, Benicky J and Saavedra JM: Minocycline ameliorates LPS-induced inflammation in human monocytes by novel mechanisms including LOX-1, Nur77 and LITAF inhibition. Biochim Biophys Acta 1820: 503-510, 2012.

82. Li H, Xu H and Sun B: Lipopolysaccharide regulates MMP-9 expression through TLR4/NF-kB signaling in human arterial smooth muscle cells. Mol Med Rep 6: 774-778, 2012.

83. Pick M, Ronen D, Yanuka O and Benvenisty N: Reprogramming of the MHC-I and its regulation by NFkB in human-induced pluripotent stem cells. Stem Cells 30: 2700-2708, 2012.

84. Xie TX, Xia Z, Zhang N, Gong W and Huang S: Constitutive NF-kB activity regulates the expression of VEGF and IL-8 and tumor angiogenesis of human glioblastoma. Oncol Rep 23: 725-732, 2010.

85. Zhao M,Zhou A, Xu L and Zhang X: The role of TLR4-mediated PTEN/PI3K/AKT/NF-kB signaling pathway in neuroinflammation in hippocampal neurons. Neuroscience 269: 93-101, 2014.

86. Pozniak PD, White $\mathrm{MK}$ and Khalili K: TNF- $\alpha / \mathrm{NF}-\kappa \mathrm{B}$ signaling in the CNS: Possible connection to EPHB2. J Neuroimmune Pharmacol 9: 133-141, 2014.

87. Matsuura Y, Ochi M, Uchio Y, Suzuki G and Iwata A: The time-dependent difference of GAP-43 expression between sensory neurons and motoneurons after peripheral nerve transection. Scand J Plast Reconstr Surg Hand Surg 33: 267-272, 1999.

88. Gordon T, You S, Cassar SL and Tetzlaff W: Reduced expression of regeneration associated genes in chronically axotomized facial motoneurons. Exp Neurol 264: 26-32, 2015.

89. Tedeschi A, Nguyen T, Puttagunta R, Gaub P and Di Giovanni S: A $\mathrm{p} 53-\mathrm{CBP} / \mathrm{p} 300$ transcription module is required for GAP-43 expression, axon outgrowth and regeneration. Cell Death Differ 16: 543-554, 2009.

90. Jiang BP, Le L, Xu LJ and Xiao PG: Minocycline inhibits ICAD degradation and the NF-kB activation induced by 6-OHDA in PC12 cells. Brain Res 1586: 1-11, 2014.

91. Kadiyala CS, Zheng L, Du Y, Yohannes E, Kao HY, Miyagi M and Kern TS: Acetylation of retinal histones in diabetes increases inflammatory proteins: Effects of minocycline and manipulation of histone acetyltransferase (HAT) and histone deacetylase (HDAC). J Biol Chem 287: 25869-25880, 2012.

92. Levkovitch-Verbin H, Waserzoog Y, Vander S, Makarovsky D and Piven I: Minocycline upregulates pro-survival genes and downregulates pro-apoptotic genes in experimental glaucoma. Graefes Arch Clin Exp Ophthalmol 252: 761-772, 2014.

93. Hassanzadeh K, Habibi-asl B, Farajnia S and Roshangar L: Minocycline prevents morphine-induced apoptosis in rat cerebral cortex and lumbar spinal cord: A possible mechanism for attenuating morphine tolerance. Neurotox Res 19: 649-659, 2011.

94. Filipovic R and Zecevic N: Neuroprotective role of minocycline in co-cultures of human fetal neurons and microglia. Exp Neurol 211: 41-51, 2008.

95. Matsukawa N, Yasuhara T, Hara K, Xu L, Maki M, Yu G, Kaneko Y, Ojika K, Hess DC and Borlongan CV: Therapeutic targets and limits of minocycline neuroprotection in experimental ischemic stroke. BMC Neurosci 10: 126, 2009. 
96.Kerr DA, Larsen T, Cook SH, Fannjiang YR, Choi E, Griffin DE, Hardwick JM and Irani DN: BCL-2 and BAX protect adult mice from lethal Sindbis virus infection but do not protect spinal cord motor neurons or prevent paralysis. J Virol 76: 10393-10400, 2002.

97.Hemendinger RA, Armstrong EJ 3rd, Radio N and Brooks BR: Neurotoxic injury pathways in differentiated mouse motor neuron-neuroblastoma hybrid (NSC-34D) cells in vitro - limited effect of riluzole on thapsigargin, but not staurosporine, hydrogen peroxide and homocysteine neurotoxicity. Toxicol Appl Pharmacol 258: 208-215, 2012.

98. Soo KY, Atkin JD, Horne MK and Nagley P: Recruitment of mitochondria into apoptotic signaling correlates with the presence of inclusions formed by amyotrophic lateral sclerosis-associated SOD1 mutations. J Neurochem 108 578-590, 2009.

99.Lee SH, Choi NY, Yu HJ, Park J, Choi H, Lee KY, Huh YM, Lee YJ and Koh SH: Atorvastatin protects NSC-34 motor neurons against oxidative stress by activating PI3K, ERK and free radical scavenging. Mol Neurobiol Jan 11, 2015 (Epub ahead of print)

100.Ezzi SA, Urushitani M and Julien JP: Wild-type superoxide dismutase acquires binding and toxic properties of ALS-linked mutant forms through oxidation. J Neurochem 102: 170-178, 2007.

101.Liu YX, Tai JL, Li GQ, Zhang ZW, Xue JH, Liu HS, Zhu H, Cheng JD, Liu YL, Li AM and Zhang Y: Exposure to $1950-\mathrm{MHz}$ TD-SCDMA electromagnetic fields affects the apoptosis of astrocytes via caspase-3-dependent pathway. PLoS One 7: e42332, 2012.

102.Ransohoff RM and Estes ML: Astrocyte expression of major histocompatibility complex gene products in multiple sclerosis brain tissue obtained by stereotactic biopsy. Arch Neurol 48: 1244-1246, 1991.

103.Kim KH, Jeong JY, Surh YJ and Kim KW: Expression of stress-response ATF3 is mediated by Nrf2 in astrocytes. Nucleic Acids Res 38: 48-59, 2010.

104.Sunkaria A, Wani WY, Sharma DR and Gill KD: Dichlorvos exposure results in activation induced apoptotic cell death in primary rat microglia. Chem Res Toxicol 25: 1762-1770, 2012.

105. Tambuyzer BR, Ponsaerts P and Nouwen EJ: Microglia: Gatekeepers of central nervous system immunology. J Leukoc Biol 85: 352-370, 2009.
106. Simonishvili S, Jain MR, Li H, Levison SW and Wood TL: Identification of Bax-interacting proteins in oligodendrocyte progenitors during glutamate excitotoxicity and perinatal hypoxia-ischemia. ASN Neuro 5: e00131, 2013.

107. Ji Q, Castelli L and Goverman JM: MHC class I-restricted myelin epitopes are cross-presented by Tip-DCs that promote determinant spreading to CD8 ${ }^{+}$T cells. Nat Immunol 14: 254-261, 2013.

108. Goldberg J, Daniel M, van Heuvel Y, Victor M, Beyer C, Clarner T and Kipp M: Short-term cuprizone feeding induces selective amino acid deprivation with concomitant activation of an integrated stress response in oligodendrocytes. Cell Mol Neurobiol 33: 1087-1098, 2013.

109. Johanson SO, Crouch MF and Hendry IA: Retrograde axonal transport of signal transduction proteins in rat sciatic nerve. Brain Res 690: 55-63, 1995.

110. Wang HH, Hsieh HL, Wu CY and Yang CM: Oxidized low-density lipoprotein-induced matrix metalloproteinase-9 expression via PKC-delta/p42/p44 MAPK/Elk-1 cascade in brain astrocytes. Neurotox Res 17: 50-65, 2010.

111. Lively S and Schlichter LC: The microglial activation state regulates migration and roles of matrix-dissolving enzymes for invasion. J Neuroinflammation 10: 75, 2013.

112. Monnet-Tschudi F, Defaux A, Braissant O, Cagnon L and Zurich MG: Methods to assess neuroinflammation. Curr Protoc Toxicol Unit 12: 19, 2011.

113. Krum JM and Khaibullina A: Inhibition of endogenous VEGF impedes revascularization and astroglial proliferation: Roles for VEGF in brain repair. Exp Neurol 181: 241-257, 2003.

114. Shin YJ, Riew TR, Park JH, Pak HJ and Lee MY: Expression of vascular endothelial growth factor-C (VEGF-C) and its receptor (VEGFR-3) in the glial reaction elicited by human mesenchymal stem cell engraftment in the normal rat brain. J Histochem Cytochem 63: 170-180, 2015.

115. Keshavarz M, Emamghoreishi M, Nekooeian AA, J Warsh J and Zare HR: Increased bcl-2 protein levels in rat primary astrocyte culture following chronic lithium treatment. Iran J Med Sci 38: 255-262, 2013.

116. Barber SC, Higginbottom A, Mead RJ, Barber S and Shaw PJ: An in vitro screening cascade to identify neuroprotective antioxidants in ALS. Free Radic Biol Med 46: 1127-1138, 2009.

117. Prell T, Lautenschläger J, Weidemann L, Ruhmer J, Witte OW and Grosskreutz J: Endoplasmic reticulum stress is accompanied by activation of NF-kB in amyotrophic lateral sclerosis. J Neuroimmunol 270: 29-36, 2014. 